\title{
Parameters Controlling the Oxide Reduction during Sintering of Chromium Prealloyed Steel
}

\author{
Monika Hrubovčáková, ${ }^{1}$ Eva Dudrová, ${ }^{1}$ Eduard Hryha, ${ }^{2}$ \\ Margita Kabátová, ${ }^{1}$ and Jarmila Harvanová ${ }^{3}$ \\ ${ }^{1}$ Institute of Materials Research of SAS, Watsonova 47, 04001 Košice, Slovakia \\ ${ }^{2}$ Department of Materials and Manufacturing Technology, Chalmers University of Technology, Rännvägen 2A, \\ 41296 Göteborg, Sweden \\ ${ }^{3}$ University of Veterinary Medicine and Pharmacy, Komenskeho 73, 04181 Košice, Slovakia
}

Correspondence should be addressed to Monika Hrubovčáková; mhrubovcakova@imr.saske.sk

Received 21 May 2013; Accepted 28 August 2013

Academic Editor: Jörg M. K. Wiezorek

\begin{abstract}
Copyright @ 2013 Monika Hrubovčáková et al. This is an open access article distributed under the Creative Commons Attribution License, which permits unrestricted use, distribution, and reproduction in any medium, provided the original work is properly cited.

Temperature intervals of oxide reduction processes during sintering of the Fe-3\%Cr-0.5\%Mo prealloyed powder using continuous monitoring of processing-exhaust gas composition $\left(\mathrm{CO}, \mathrm{CO}_{2}\right.$, and $\left.\mathrm{H}_{2} \mathrm{O}\right)$ were identified and interpreted in relation to density (6.5$\left.7.4 \mathrm{~g} / \mathrm{cm}^{3}\right)$, sintering temperature $\left(1120\right.$ and $\left.1200^{\circ} \mathrm{C}\right)$, heating and cooling rates $\left(10\right.$ and $\left.50^{\circ} \mathrm{C} / \mathrm{min}\right)$, carbon addition $(0.5 / 0.6 / 0.8 \%)$, type $\left(10 \% \mathrm{H}_{2}-\mathrm{N}_{2}, \mathrm{~N}_{2}\right)$, and purity $(5.0$ and 6.0$)$ of the sintering atmosphere. The progress in reduction processes was evaluated by oxygen and carbon contents in sintered material and fracture strength values as well. Higher sintering temperature $\left(1200^{\circ} \mathrm{C}\right)$ and density $<7.0 \mathrm{~g} / \mathrm{cm}^{3}$ resulted in a relative decrease of oxygen content by more than $80 \%$. The deterioration of microclimate purity of inner microvolumes of compacts shifted the thermodynamic equilibrium towards oxidation. It resulted in a closing of residual oxides inside interparticle necks. The reducing ability of the $\mathrm{N}_{2}$ atmosphere can be improved by sintering in a graphite container. High density of $7.4 \mathrm{~g} / \mathrm{cm}^{3}$ achieved by double pressing indicated a negative effect on reduction processes due to restricted replenishment of the microclimate atmosphere with the processing gas. In terms of strength properties, carbon content should not be higher than $\sim 0.45 \%$.
\end{abstract}

\section{Introduction}

Modern manufacturing techniques allow production of highpurity chromium alloyed powders [1-5] excellently predisposed to the production of structural, even highly stressed components. However, uncontrolled changes in the surface oxide composition can be obtained during sintering [6-12]. The consistent solution of this problem will mean a removal of any differences between the properties of chromiumalloyed sintered steels and most commonly used (but considerably more expensive) diffusion-alloyed powder grades.

In the literature, especially over the last $10-15$ years, a lot of information and thermodynamical data on reduction reactions during sintering of $\mathrm{Cr}$ and $\mathrm{Mn}$ alloyed steels with respect to various processing conditions were presented [1121].
The importance of several sintering parameters, like sintering temperature, type and composition of sintering atmosphere, density, carbon content, and so forth, has been widely discussed. However, there are relatively few studies systematically dealing with the influence of heating and cooling rates during sintering and particularly with the effect of green density on oxide transformation. In this way, the effect of density and pore characteristics on oxide transformation can be established as key parameters that control the redox reactions during sintering. Mitchell et al. [15, 16] and Hryha et al. [17-20] presented a thermodynamic solution for this problem, which is based on the calculation of maximum tolerable partial pressure of active components $\left(\mathrm{CO}, \mathrm{CO}_{2}\right.$, and $\left.\mathrm{H}_{2} \mathrm{O}\right)$ in the processing gases during sintering. As pointed out by Hryha et al. [21], during sintering of powder steels alloyed with elements with a high affinity to 
oxygen, special attention should be paid to the evolution of reduction/oxidation processes for the critical stage of sintering, which is the heating stage.

During sintering, depending on temperature, sintering atmosphere composition, and base material, the ongoing chemical reactions alter the composition of processing gases [22-25].

The carbothermal reduction controlled by the partial pressures of $\mathrm{CO}$ and $\mathrm{CO}_{2}$ (whose ratio is controlled by Boudouard, equilibrium) plays a crucial role in the reduction of thermodynamically stable chromium oxides [25-30]. Significant knowledge of the chemical interactions during the sintering of Cr-alloyed steels has been reported by Danninger et al. [31-35]. Based on thermodynamic calculations, Hryha et al. $[7,11,12]$ reported the reduction sequence of several Fe-, $\mathrm{Cr}-, \mathrm{Mn}-$, and Si-based oxides in relation to temperature:

$$
\begin{aligned}
\mathrm{Fe}_{2} \mathrm{O}_{3} & \longrightarrow \mathrm{FeO} \longrightarrow \mathrm{Fe}_{2} \mathrm{MnO}_{4} \longrightarrow \mathrm{Cr}_{2} \mathrm{FeO}_{4} \longrightarrow \mathrm{Cr}_{2} \mathrm{O}_{3} \\
& \longrightarrow \mathrm{MnCr}_{2} \mathrm{O}_{4} \longrightarrow \mathrm{MnO} \longrightarrow \mathrm{MnSiO}_{3} \longrightarrow \mathrm{SiO}_{2}
\end{aligned}
$$

It is important to emphasize that chemical reactions occurring between the flowing furnace atmosphere and external surface of powder compacts may be quite different from the reactions that take place in the inner volume of pores of the compact, where so-called "microclimates" are formed [15]. The equilibrium state in a microclimate inside the compact is formed between carbon, oxygen, water vapour, and metallic/oxide surface of the base material. Hryha and Dudrova [19] analyzed the microclimate effect on the reduction/oxidation behaviour and on the sintering of mixed and prealloyed manganese steels. The microclimate composition which controls the reduction/oxidation processes in internal pores can only be observed indirectly. However, it has been found that at moderate density (around $7.0 \mathrm{~g} / \mathrm{cm}^{3}$ ) the furnace atmosphere, at a sufficient purity and a high flowing rate, has a significant effect on the microclimate composition $[36,37]$.

Hence, the contribution deals with the study of the effect of green density, sintering parameters (temperature, sintering atmosphere composition, and heating and cooling rates), and carbon content on reduction processes during sintering of the $\mathrm{Fe}-3 \% \mathrm{Cr}-0.5 \%$ Mo steel powder. The influence of the abovementioned parameters was studied by continuous analysis of evolved processing gases composition over the whole sintering cycle. Efficiency of oxide reduction was evaluated by oxygen and carbon contents in the sintered material. The effect of residual oxide on material performance was evaluated by fracture strength of sintered components.

\section{Experimental Procedure}

The material used in this investigation was water-atomized Fe-Cr-Mo steel powder (AstCrM, Höganäs AB, Sweden) with nominal composition of Fe-3 wt.\% Cr- 0.5 wt.\% Mo. Chemical analysis of the AstCrM powder used is given in Table 1.

Starting powder was admixed with $0.5,0.6$, and 0.8 wt.\% of carbon in the form of natural graphite Kropfmühl UF4. After homogenization of powder mixes in Turbula mixer,
TABLE 1: Chemical composition of AstCrM powder used.

\begin{tabular}{lcccccccc}
\hline Element & $\mathrm{Cr}$ & $\mathrm{Mo}$ & $\mathrm{Mn}$ & $\mathrm{Si}$ & $\mathrm{Al}$ & $\mathrm{C}$ & $\mathrm{O}_{2}$ & $\mathrm{Fe}$ \\
\hline wt.\% & 3.0 & 0.48 & 0.037 & 0.089 & 0.025 & 0.019 & 0.197 & Balance \\
\hline
\end{tabular}

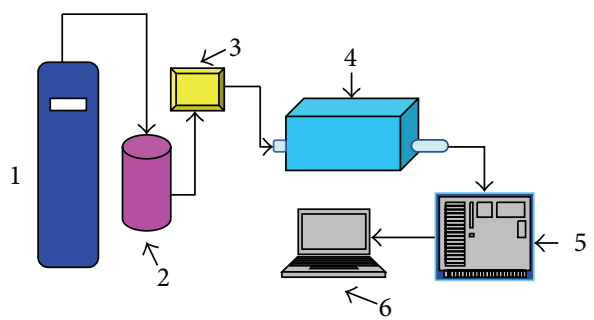
(1) Gas cylinder $\left(10 \% \mathrm{H}_{2} / \mathrm{N}_{2}\right.$ mixture)
(2) Liquid nitrogen dryer
(3) Hygrolog (inlet dew-point)
(4) Furnace (ANETA)
(5) $\mathrm{CO} / \mathrm{CO}_{2} / \mathrm{H}_{2} \mathrm{O}$ analyzer
(6) PC

FIGURE 1: Scheme of sintering atmosphere monitoring setup, sintering furnace, and PC processing of the monitored data.

the cylindrical samples $\varnothing 10 \times 12 \mathrm{~mm}^{3}$ were compacted to densities of $6.5,6.8,7.1$, and $7.4 \mathrm{~g} / \mathrm{cm}^{3}$, respectively. The density of $7.4 \mathrm{~g} / \mathrm{cm}^{3}$ was obtained using double pressing technique, including compaction at the pressure of $600 \mathrm{MPa}$ followed by annealing at $750^{\circ} \mathrm{C}$ for 15 minutes in $10 \% \mathrm{H}_{2}-\mathrm{N}_{2}$ atmosphere and repressing at $800 \mathrm{MPa}$. The sintering at 1120 and $1200^{\circ} \mathrm{C}$ for $30 \mathrm{~min}$ using two different heating and cooling rates, 10 and $50^{\circ} \mathrm{C} / \mathrm{min}$, was carried out in a laboratory tube furnace ANETA 1 that allows working temperatures up to $1250^{\circ} \mathrm{C}$.

The furnace constitutes a part of the sintering atmosphere monitoring setup originally installed at IMR SAS laboratory [17] (see scheme in Figure 1). Its arrangement allows in-line analysis of the exhaust gases content $\left(\mathrm{CO}, \mathrm{CO}_{2}\right.$, and $\left.\mathrm{H}_{2} \mathrm{O}\right)$ during whole sintering cycle up to the temperature of $1200^{\circ} \mathrm{C}$. The processing atmosphere used was a mixture of $10 \% \mathrm{H}_{2}-\mathrm{N}_{2}$ purity $5.0\left(\mathrm{O}_{2}\right.$ content $1.0 \mathrm{ppm}, \mathrm{H}_{2} \mathrm{O}$ content $\left.3.2 \mathrm{ppm}\right)$ and purity $6.0\left(\mathrm{O}_{2}\right.$ content $0.3 \mathrm{ppm}, \mathrm{H}_{2} \mathrm{O}$ content $\left.0.5 \mathrm{ppm}\right)$ and $\mathrm{N}_{2}$-atmosphere $\left(\mathrm{O}_{2}\right.$ content $1.1 \mathrm{ppm}, \mathrm{H}_{2} \mathrm{O}$ content $\left.3 \mathrm{ppm}\right)$, from MESSER.

Particular attention was given to processing atmosphere purity that was solved by atmosphere drying using liquid nitrogen dryer. It consists of thin brass tubes immersed into a container with liquid nitrogen through which the atmosphere is blown which allows an efficient entrapment of the water vapour by its freezing. Therefore, the dew point of the inlet atmosphere, monitored by Super-Dew SHAW hygrolog, was $-68^{\circ} \mathrm{C}$. The flow rate of the atmosphere used was $21 / \mathrm{min}$. Open ferritic stainless steel container and sampling tubes were utilized for exhaust atmosphere sampling. In each experiment, six identical samples were kept in container. The processing atmosphere was continually sampled directly from the container near the specimen surfaces using ferritic stainless tube (see Figure 2). 


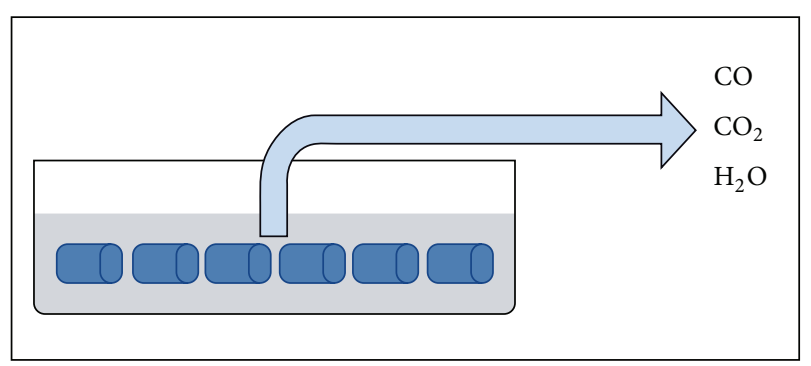

FIGURE 2: Scheme of sampling the atmosphere from the container.
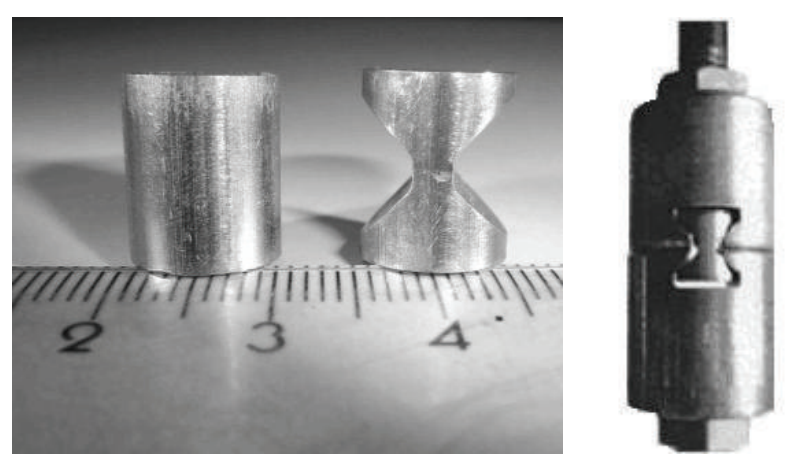

Figure 3: The shape of samples and equipment to the "button cell test."

The dew point of the sampled gases was monitored using Michell Cermet II sensor. $\mathrm{CO}$ and $\mathrm{CO}_{2}$ contents were measured by use of nondispersed infrared analyzers on the base of Gas Card II Plus sensor. All sensors were connected to a $\mathrm{PC}$, and continuous recording of the $\mathrm{CO}, \mathrm{CO}_{2}$, and $\mathrm{H}_{2} \mathrm{O}$ contents was performed by using special software.

The powder particles surface was studied by highresolution scanning electron microscopy (LEO Gemini 1550). Microstructure was observed using light (Olympus GX 71) and scanning electron microscopy (Jeol JSM 7000F coupled with INCA EDX analyzer). Oxygen and carbon contents in sintered components were provided using LECO TC 36 instrument. Hereinafter presented contents of oxygen and carbon are mean values of three measurements with the spread less than $5 \%$. The fracture strength, $R_{\mathrm{FR}}$, was evaluated using nonstandard "button" tensile test method; buttonshaped samples were prepared by mechanical machining of the sintered cylinders; see Figure 3.

\section{Results}

3.1. Surface of the Starting Powder. The surface of the wateratomized chromium pre-alloyed powder is covered by heterogeneous surface oxides composed of thin Fe-oxide layer and particulate features rich in strong oxide forming elements; see also [6-10]. In Figure 4(a), appearance of the typical surface of the starting powder is presented. Figure 4(b) shows the presence of particulate features with characteristic spherical shape and sizing up to $200 \mathrm{~nm}$. Semiquantitative EDX analyses of these spherical particulates confirmed the presence of $\mathrm{Cr}, \mathrm{Mn}, \mathrm{Si}, \mathrm{Fe}$, and $\mathrm{O}$. It is in agreement with the results of Karlsson et al. [6, 8] and Hryha et al. [9-12] that described these as thermodynamically stable complex oxides typical of the water-atomized chromium pre-alloyed powder. Distribution of oxide particles can be evaluated as more or less random, with no pronounced preference, as reported by other authors.

3.2. Effect of Density and Sintering Temperature on Reduction Processes. In Figures 5(a)-5(d) are the spectra of the processing gas composition during the whole sintering cycle at $1200^{\circ} \mathrm{C}$ for all the tested densities of the AstCrM $+0.5 \%$ $\mathrm{C}$ components. The heating rate was $10^{\circ} \mathrm{C} / \mathrm{min}$, cooling rate $-50^{\circ} \mathrm{C} / \mathrm{min}$. Profile of curves of the $\mathrm{H}_{2} \mathrm{O}, \mathrm{CO}_{2}$, and $\mathrm{CO}$ contents provides information on gas evolution due to respective chemical reactions and their temperature intervals during sintering. The temperature of the peaks recorded $\left(\mathrm{H}_{2} \mathrm{O}, \mathrm{CO}\right.$, and $\mathrm{CO}_{2}$ profiles $)$ and corresponding amounts of active constituent in sampled gas in relation to the density is summarized in Tables 2(a)-2(c). Other useful information on reduction processes during the heating stage and isothermal sintering is provided by the mass changes together with the oxygen and carbon contents and fracture strength listed in Tables 3 and 4.

The reduction processes take place in two temperature intervals. During the heating, the surface layer of iron oxides is reduced by hydrogen from sintering atmosphere. Carbothermal reduction of more stable oxides is theoretically possible after Boudouard's equilibrium $\left(\sim 720^{\circ} \mathrm{C}\right)$; however, experimentally evident reduction by graphite is observed at higher temperatures [20]. Reduction of the internal oxides is possible after dissolution of carbon in the steel matrix meaning after $\alpha-\gamma$ transformation.

The first peak on $\mathrm{H}_{2} \mathrm{O}$ profile (Figure 5 and Table 2(a)) was observed at $180-195^{\circ} \mathrm{C}$ depending on the density and is connected to the removal of physically bonded water. The reduction of continuous layer of surface iron oxide $\left(\mathrm{Fe}_{2} \mathrm{O}_{3}\right)$ by hydrogen starts at about $\sim 300^{\circ} \mathrm{C}$, and depending on the density it reaches a maximum at $450-513^{\circ} \mathrm{C}$. This peak is also linked with the decomposition of the hydrocarbonates, created on the particle surfaces during powder handling. The peak temperature as well as the peak width clearly increases together with density. This indicates that, in the case of more dense compacts, the atmosphere penetration is restricted both ways-inwards and outwards. This corresponds to a lower amount of $\mathrm{H}_{2} \mathrm{O}$ recorded at higher densities (see Table $2(\mathrm{a}))$. The peaks above $1000^{\circ} \mathrm{C}\left(1100-1196^{\circ} \mathrm{C}\right)$ are related to the reduction of iron-rich oxides from internal pores.

The reducing activity of hydrogen decreases with an increase in temperature. Further reduction processes above $700^{\circ} \mathrm{C}$ occurred as carbothermal reduction processes indicated by $\mathrm{CO}$ formation. Carbothermal reduction of iron oxides by plain carbon in $\mathrm{Fe}-\mathrm{C}$ contacts reaches a maximum for densities of 6.5 and $6.8 \mathrm{~g} / \mathrm{cm}^{3}$ at $802^{\circ} \mathrm{C}$ and $820^{\circ} \mathrm{C}$; for densities of 7.1 and $7.4 \mathrm{~g} / \mathrm{cm}^{3}$, it is 836 and $840^{\circ} \mathrm{C}$.

At higher temperature, there are two maxima of $\mathrm{CO}$ profile: the peak at $1081^{\circ} \mathrm{C}$ for density $6.5 \mathrm{~g} / \mathrm{cm}^{3}$ and $1120^{\circ} \mathrm{C}$ for density $6.8 \mathrm{~g} / \mathrm{cm}^{3}$ and are connected with the carbothermal reduction of thermodynamically more stable surface $\mathrm{Fe}$ $\mathrm{Cr}$ oxides and, probably, oxides from semiclosed internal 
TABLE 2: (a) Effect of the component density on the temperature of the peaks on $\mathrm{H}_{2} \mathrm{O}$ profile and corresponding amounts of active constituent in sampled gas. (b) Effect of the component density on the temperature of the peaks on CO profile and corresponding amounts of active constituent in sampled gas. (c) Effect of the component density on the temperature of the peaks on $\mathrm{CO}_{2}$ profile and corresponding amounts of active constituent in sampled gas.

(a)

\begin{tabular}{lcccccc}
\hline & \multicolumn{2}{c}{} & \multicolumn{2}{c}{$\mathrm{H}_{2} \mathrm{O}$} \\
2nd peak & \multicolumn{3}{c}{ 3rd peak } \\
& \multicolumn{2}{c}{ 1st peak } & \multicolumn{2}{c}{ 2nd level $\left(\mathrm{g} / \mathrm{cm}^{3}\right)$} & & \multicolumn{2}{c}{} \\
& Temperature $\left({ }^{\circ} \mathrm{C}\right)$ & Dew point $\left({ }^{\circ} \mathrm{C}\right)$ & Temperature $\left({ }^{\circ} \mathrm{C}\right)$ & Dew point $\left({ }^{\circ} \mathrm{C}\right)$ & Temperature $\left({ }^{\circ} \mathrm{C}\right)$ & Dew point $\left({ }^{\circ} \mathrm{C}\right)$ \\
\hline 6.5 & 180 & -42.4 & 450 & -18.0 & 1081 & -32.4 \\
6.8 & 180 & -41.4 & 470 & -18.2 & 1126 & -34.9 \\
7.1 & 195 & -36.9 & 503 & -27.2 & 1185 & -33.8 \\
7.4 & 195 & -36.4 & 513 & -29.5 & 1184 & -36.9 \\
\hline
\end{tabular}

(b)

\begin{tabular}{lcccccc}
\hline & \multicolumn{2}{c}{} & \multicolumn{2}{c}{ CO } & \multicolumn{2}{c}{} \\
Density level $\left(\mathrm{g} / \mathrm{cm}^{3}\right)$ & \multicolumn{2}{c}{ 1st peak } & \multicolumn{2}{c}{ 2nd peak } & \multicolumn{2}{c}{ 3rd peak } \\
& Temperature $\left({ }^{\circ} \mathrm{C}\right)$ & Content $(\mathrm{ppm})$ & Temperature $\left({ }^{\circ} \mathrm{C}\right)$ & Content $(\mathrm{ppm})$ & Temperature $\left({ }^{\circ} \mathrm{C}\right)$ & Content $(\mathrm{ppm})$ \\
\hline 6.5 & 802 & 180 & 1081 & 1148 & 1200 & 2234 \\
6.8 & 820 & 109 & 1120 & 1172 & 1200 & 2205 \\
7.1 & 836 & 219 & - & - & 1200 & 2221 \\
7.4 & 840 & 249 & - & - & 1200 & 2218 \\
\hline
\end{tabular}

(c)

\begin{tabular}{lcc}
\hline Density level $\left(\mathrm{g} / \mathrm{cm}^{3}\right)$ & $\mathrm{CO}_{2}$ \\
\hline 6.5 & Temperature $\left({ }^{\circ} \mathrm{C}\right)$ & Content $(\mathrm{ppm})$ \\
6.8 & 320 & 139 \\
7.1 & 320 & 154 \\
7.4 & 350 & 201 \\
\hline
\end{tabular}

TABLE 3: The mass change, oxygen and carbon contents, and fracture strength of the AstCrM $+0.5 \% \mathrm{C}$ material heated to 730 , 1120 , and $1200^{\circ} \mathrm{C}$ and cooled at $50^{\circ} \mathrm{C} / \mathrm{min}$ in relation to density.

\begin{tabular}{lcccccc}
\hline Density level $\left(\mathrm{g} / \mathrm{cm}^{3}\right)$ & Temperature $\left({ }^{\circ} \mathrm{C}\right)$ & Sintered density $\left(\mathrm{g} / \mathrm{cm}^{3}\right)$ & Mass change $(\%)$ & $\mathrm{O}_{2}(\%)$ & $\mathrm{C}(\%)$ & $R_{\mathrm{FR}}(\mathrm{MPa})$ \\
\hline \multirow{3}{*}{6.5} & 730 & 6.55 & 0.016 & 0.199 & 0.48 & - \\
& 1120 & 6.55 & -0.116 & 0.124 & 0.40 & 557 \\
& 1200 & 6.60 & -0.225 & 0.069 & 0.36 & 752 \\
\hline \multirow{2}{*}{6.8} & 730 & 6.89 & 0.003 & 0.209 & 0.48 & - \\
& 1120 & 6.83 & -0.104 & 0.144 & 0.44 & 693 \\
& 1200 & 6.84 & -0.329 & 0.092 & 0.38 & 731 \\
7.1 & 730 & 7.09 & -0.056 & 0.214 & 0.48 & - \\
& 1120 & 7.08 & -0.105 & 0.167 & 0.45 & 704 \\
& 1200 & 7.12 & -0.210 & 0.136 & 0.40 & 954 \\
\hline
\end{tabular}

pores. With density increasing, the reduction of oxides in the core of compact becomes more difficult as the removal of reaction products from internal pores is difficult, which also corresponds to a smaller amount of $\mathrm{CO}$ registered for higher densities (see Table 2(b)). In the case of densities of 7.1 and $7.4 \mathrm{~g} / \mathrm{cm}^{3}$, the peak at $1120^{\circ} \mathrm{C}$ has not been recorded. As reported in $[20,21]$, the reduction of thermodynamically stable surface oxides Fe-Cr-Mn and iron-rich oxides from internal pores is shifted to $1120^{\circ} \mathrm{C}$. Internal thermodynamically more stable $\mathrm{Cr}-\mathrm{Mn}-\mathrm{Si}$ spinel oxides typically require temperatures above $1200^{\circ} \mathrm{C}$. There is only one peak at $1200^{\circ} \mathrm{C}$ for all tested densities. It evidently shows that with increasing density the communication of inner pores with compacts surface is restricted, and hence oxide reduction is retarded. The $\mathrm{CO}_{2}$ peak at $320-380^{\circ} \mathrm{C}$ is linked with graphite oxidation as well as dissociation of the hydrocarbides, formed on the powder surface during powder handling.

The presented results obtained by monitoring the composition of processing gases are in agreement with the results obtained at degassing experiments with DTA, DTG, and mass 
TABLE 4: Mass changes and oxygen and carbon contents in the AstCrM $+0.5 \% \mathrm{C}$ material isothermal sintered at 1120 and $1200^{\circ} \mathrm{C}$ for $30 \mathrm{~min}$ in relation to density.

\begin{tabular}{lcccccc}
\hline Density level $\left(\mathrm{g} / \mathrm{cm}^{3}\right)$ & Temperature $\left({ }^{\circ} \mathrm{C}\right)$ & Sintered density $\left(\mathrm{g} / \mathrm{cm}^{3}\right)$ & Mass change $(\%)$ & $\mathrm{O}_{2}(\%)$ & $\mathrm{C}(\%)$ & $R_{\mathrm{FR}}(\mathrm{MPa})$ \\
\hline \multirow{2}{*}{6.5} & 1120 & 6.57 & -0.230 & 0.098 & 0.42 & 562 \\
& 1200 & 6.64 & -0.312 & 0.025 & 0.36 & 838 \\
\hline \multirow{2}{*}{6.8} & 1120 & 6.80 & -0.297 & 0.097 & 0.42 & 754 \\
& 1200 & 6.89 & -0.356 & 0.027 & 0.37 & 954 \\
\hline \multirow{2}{*}{7.1} & 1120 & 7.11 & -0.245 & 0.133 & 0.43 & 929 \\
& 1200 & 7.10 & -0.291 & 0.068 & 0.39 & 966 \\
\hline \multirow{2}{*}{7.4} & 1120 & 7.39 & -0.102 & 0.156 & 0.45 & 416 \\
& 1200 & 7.39 & -0.174 & 0.151 & 0.41 & 612 \\
\hline
\end{tabular}

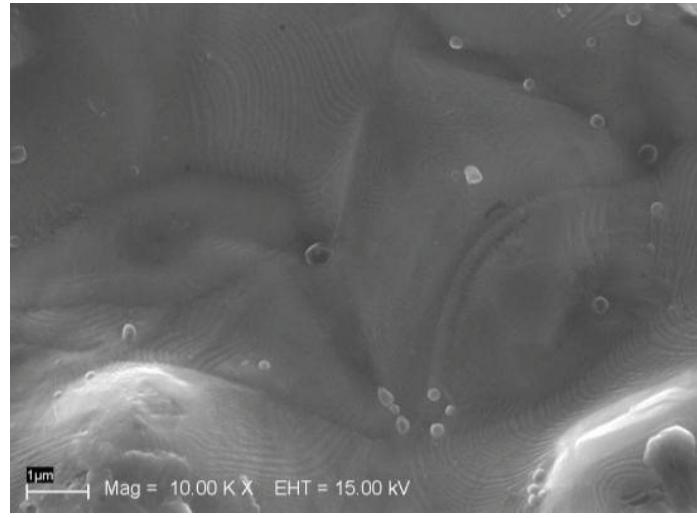

(a)

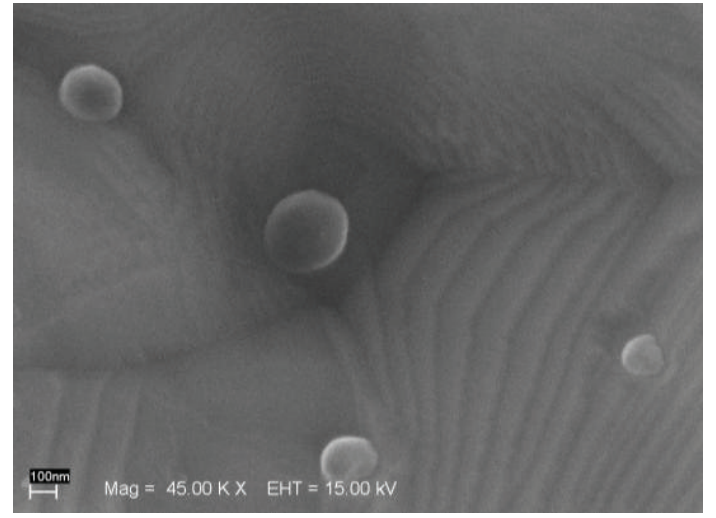

(b)

Figure 4: (a) Typical surface of the AstCrM particle and (b) spherical particulate features on powder particle surface.

spectroscopy analysis as was reported by Danninger et al. [3135].

When analyzing the changes in the mass of the compacts as well as the oxygen and carbon contents during the heating stage (Table 3 ) the effect of the density and temperature is evident as well. During the heating to $730^{\circ} \mathrm{C}$, the mass gain was recorded for all three densities studied with corresponding relative increase in oxygen content over starting point between 1 and $~ 9 \%$ which also increases with density. This once again indicates more efficient reduction of the surface oxides in the case of the low-density compacts but also is affected by reoxidation during cooling stage. During the heating stage to $1120^{\circ} \mathrm{C}$, as well as to $1200^{\circ} \mathrm{C}$, the mass loss and oxygen content decreasing were identified for all studied densities. Lower values of the mass loss as well as lower oxygen content were obtained with increasing density confirming surface re-oxidation of the compacts during the cooling stage.

During the isothermal sintering at 1120 and $1200^{\circ} \mathrm{C}$, the mass loss increased and the oxygen content decreased (see Table 4) with obvious positive effect of higher sintering temperature. Simultaneously, the negative effect of higher density on the final oxygen content that was recorded for heating stage was confirmed. The relative decrease in oxygen content over the starting point by $\sim 50 \%$ during sintering at $1120^{\circ} \mathrm{C}$ was identified for densities of 6.5 and $6.8 \mathrm{~g} / \mathrm{cm}^{3}$; for density of $7.1 \mathrm{~g} / \mathrm{cm}^{3}$, it was by $\sim 32 \%$, and for $7.4 \mathrm{~g} / \mathrm{cm}^{3}$ it was only $\sim 21 \%$. Larger decrease in oxygen content was recorded during the sintering at $1200^{\circ} \mathrm{C}$. At densities of 6.5 and $6.8 \mathrm{~g} / \mathrm{cm}^{3}$, it was $\sim 87 \%$; for density of $7.1 \mathrm{~g} / \mathrm{cm}^{3}$ it was $\sim 65 \%$, and for $7.4 \mathrm{~g} / \mathrm{cm}^{3}$ only $23 \%$.

A similar trend in the development of the carbon content with increasing density is seen for both heating stage and isothermal sintering. It should be noted that such behaviour of high-density compacts is caused by employing double pressing in their preparation. As it was emphasized in [22], the most critical stage during sintering of Cr-Mn alloyed steel powders is the temperature interval around $800-900^{\circ} \mathrm{C}$, as the mass transfer of the alloying elements as $\mathrm{Cr}$ and $\mathrm{Mn}$ is rather high, but thermodynamic conditions inside the pores are really poor which leads to oxide transformation from iron-based oxides to more stable $\mathrm{Cr}-\mathrm{Mn}$ oxides that are difficult to reduce at typically used sintering temperatures. As repressing requires annealing at around $800^{\circ} \mathrm{C}$, such oxide transformation cannot be avoided and can be only minimized by proper adjustment of the temperature, time, and atmosphere. Additionally, with the repressing with closure of residual air in the pores happens. Hence, highdensity, thermodynamically more stable oxides, and closed pores cause displacement of the thermodynamic balance to 


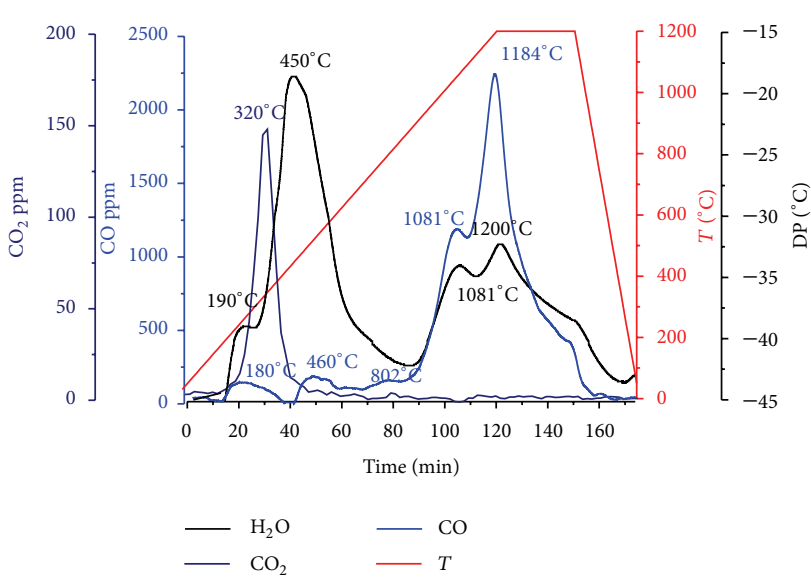

(a) $6.5 \mathrm{~g} / \mathrm{cm}^{3}$

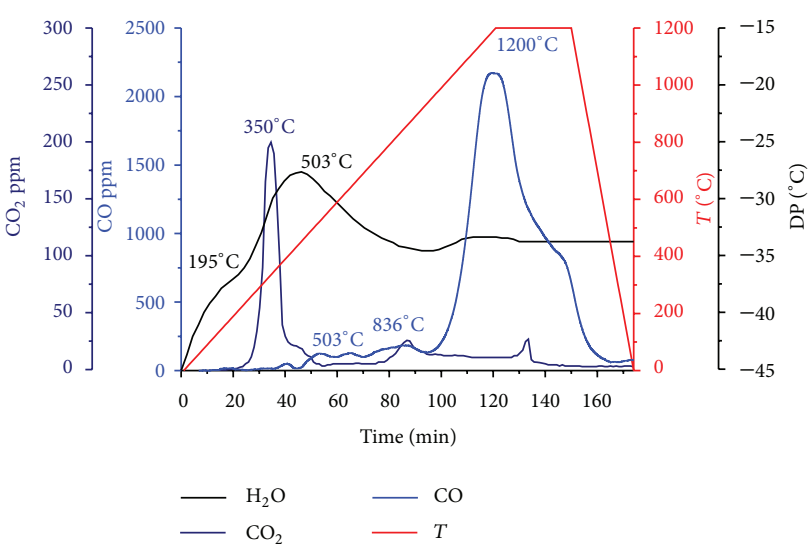

(c) $7.1 \mathrm{~g} / \mathrm{cm}^{3}$

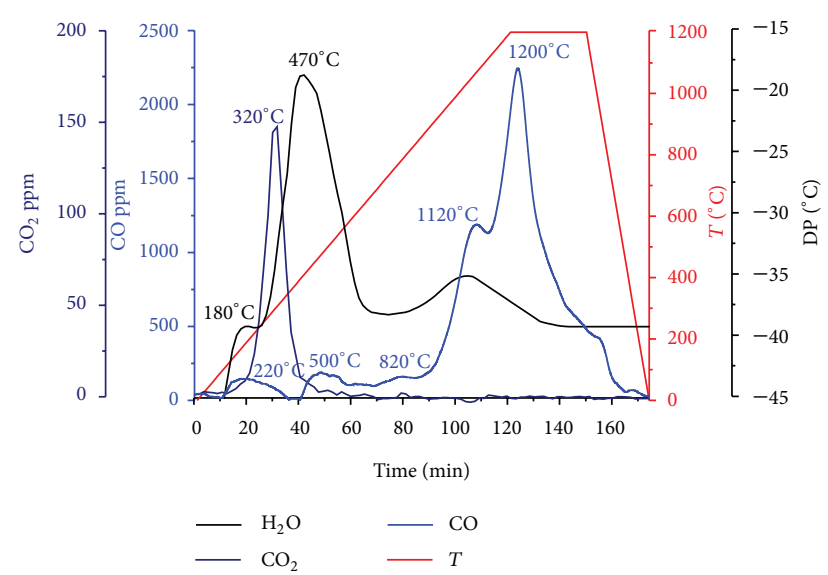

(b) $6.8 \mathrm{~g} / \mathrm{cm}^{3}$

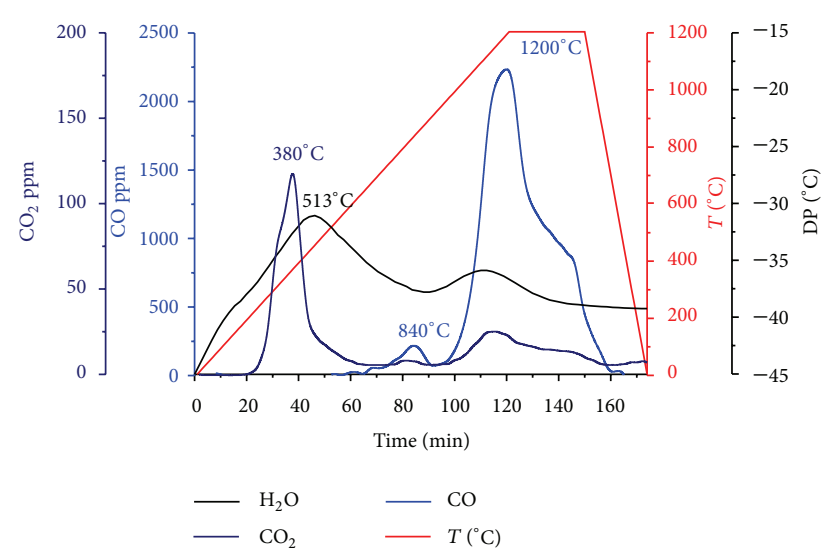

(d) $7.4 \mathrm{~g} / \mathrm{cm}^{3}$

FIGURE 5: (a)-(d) Spectra of the processing gas composition monitoring during the whole sintering cycle at $1200^{\circ} \mathrm{C}$ of the AstCrM $+0.5 \% \mathrm{C}$ compacts' densities of $6.5,6.8,7.1$, and $7.4 \mathrm{~g} / \mathrm{cm}^{3}$, respectively.

the oxidation conditions in some microclimates which is reflected in both lower mass loss and higher oxygen content. This was also confirmed by very low decrease in oxygen content for compacts with the highest density even when sintering temperature was increased from 1120 to $1200^{\circ} \mathrm{C}$ that was very beneficial for lower densities.

The rate of reduction processes with positive effect of higher sintering temperature together with oxygen content reflects on the fracture strength values; see Tables 3 and 4. In accordance with higher oxygen content and thus a slower reduction processes, there has been a decrease in fracture strength at the density of $7.4 \mathrm{~g} / \mathrm{cm}^{3}$.

3.2.1. Oxide Inclusions in Sintered Microstructure. Micrographs in Figures 6 and 7 show a difference in the amount and arrangement of oxide particles in relation to the density and sintering temperature. For low-density compacts, the oxides are present in the form of isolated particles (see Figure 6(a)) with decreasing their number at higher sintering temperature (Figure $7(\mathrm{a})$ ). At the density of $7.1 \mathrm{~g} / \mathrm{cm}^{3}$, the oxide contamination is slightly higher and oxides are arranged in the form of discontinuous chains along original particle surfaces. At higher sintering temperature, the amount of oxide decreases oxide chains become shorter and less continuous (Figures 6(b) and 7(b)). Evidently, a greater amount of likewise arranged oxides was found in compacts with density of $7.4 \mathrm{~g} / \mathrm{cm}^{3}$. As shown in Figures $7(\mathrm{a})-7(\mathrm{c})$, the amount and size of the oxide inclusions decrease.

The fracture surface observation of low-density components sintered at both temperatures showed the interparticle ductile failure with small equiaxed dimples initiated by carbides from bainitic microstructure and sporadically even with small oxide particles sized up to $\sim 1 \mu \mathrm{m}$ (see Figures 8 and 9). Higher sintering temperature led to forming structurally more improved interparticle necks with lower amount of oxide inclusions, and the failure process was accompanied with the development of local plastic flow.

This explains the increase of fracture strength values from $562 \mathrm{MPa}$ to $838 \mathrm{MPa}$ for sintering at the temperature of $1200^{\circ} \mathrm{C}$.

For more dense compacts, the areas of interparticle ductile failure were extended, but the dimples were visibly larger and flatter. Figures 8(b) and 9(b), for failed components with density of $7.4 \mathrm{~g} / \mathrm{cm}^{3}$, show that shallow dimples usually 


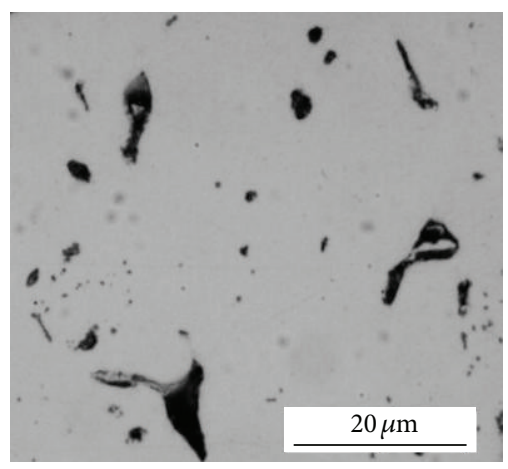

(a)

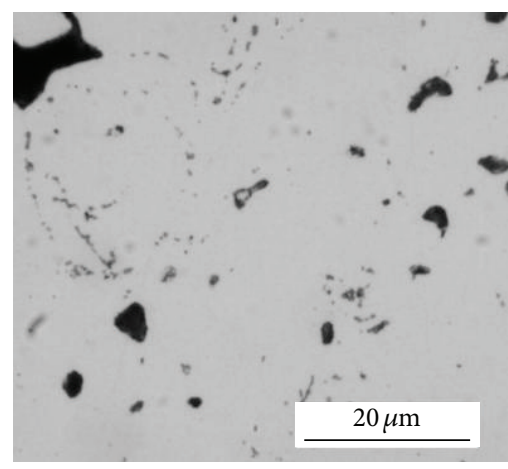

(b)

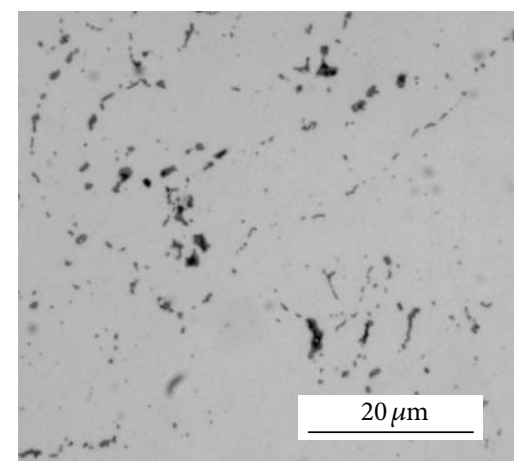

(c)

Figure 6: Oxide inclusions in AstCrM + 0.5\% C components' densities of (a) 6.5 , (b) 7.1 , and (c) $7.4 \mathrm{~g} / \mathrm{cm}^{3}$ sintered at $1200^{\circ} \mathrm{C}$ for $30 \mathrm{~min}$.

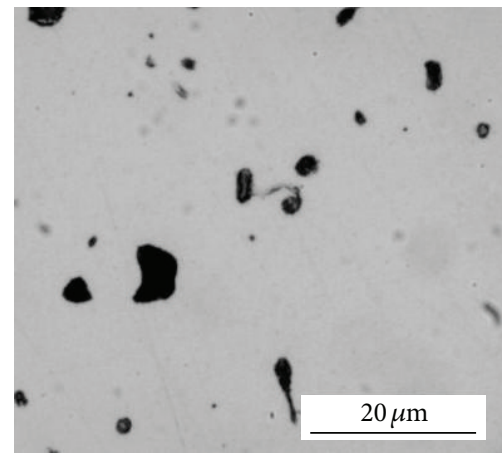

(a)

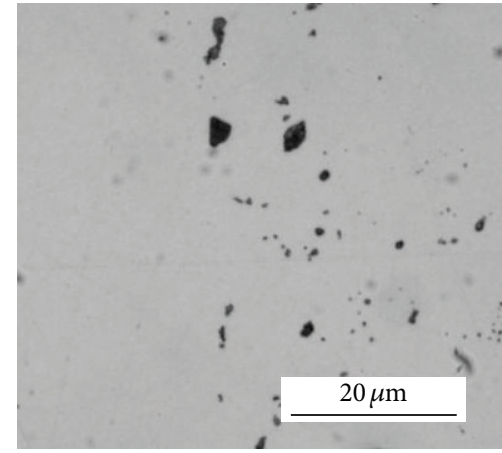

(b)

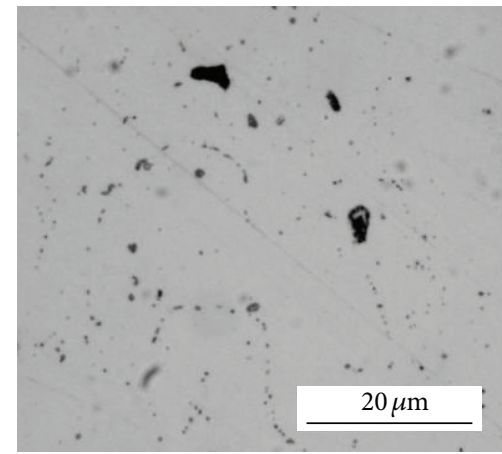

(c)

Figure 7: Oxide inclusions in AstCrM + 0.5\% C components' densities of (a) 6.5, (b) 7.1, and (c) $7.4 \mathrm{~g} / \mathrm{cm}^{3}$ sintered at $1120^{\circ} \mathrm{C}$ for $30 \mathrm{~min}$.

contain oxide inclusions or their agglomerates sized up to $\sim 5 \mu \mathrm{m}$. By EDX analysis, Figure 10, the ratio of $\mathrm{Cr}: \mathrm{Mn}$ in these oxide particles is close to $2: 1$, confirming that these are spinel-type oxides of $\mathrm{Cr}-\mathrm{Mn}$-Si. Higher sintering temperature led to the development of better connection, but without significant improvement in the reduction of oxides in closed microvolume of connections. The achieved fracture strength is lower that one for compacts with lower density.

3.3. Effect of Heating and Cooling Rates. In order to study the effect of heating and cooling rates on final oxygen content, two different heating and cooling rates, $10^{\circ} \mathrm{C} / \mathrm{min}$ and $50^{\circ} \mathrm{C} / \mathrm{min}$, were applied. The data in Table 5 show an evident tendency for increasing oxygen content at faster heating and slower cooling rates. On the contrary, the combination of slower heating and faster cooling rate proved to be most favourable. The trend of oxygen content dependency on heating and cooling rates is maintained for all densities studied. Various combinations of heating and cooling rates during sintering at $1120^{\circ} \mathrm{C}$ have only low effect on relative carbon loss which was in the range from 14 to $18 \%$. The highest value of carbon loss corresponds to density of $6.5 \mathrm{~g} / \mathrm{cm}^{3}$, and the lowest one to density of $7.1 \mathrm{~g} / \mathrm{cm}^{3}$ that, in combination with highest decrease in oxygen content observed for the same materials, indicates that highest carbon loss is associated with more efficient oxide reduction for low-density compacts by carbothermal reduction. Sintering at $1200^{\circ} \mathrm{C}$ leads to decrease in carbon content by $22-28 \%$, with the lowest values for the density of $7.1 \mathrm{~g} / \mathrm{cm}^{3}$, as in the case of lower sintering temperature.

The values of the fracture strength in Table 5 show that the strength of the AstCrM $+0.5 \% \mathrm{C}$ material is controlled not only by oxygen content, density, and sintering temperature, but also by cooling rate. Faster cooling rate results in the formation of mixed upper and lower bainitic structure; see Figure 11.

3.4. Effect of Purity of the Sintering Atmosphere. To evaluate the effect of purity of the sintering atmosphere on reduction of oxides in AstCrM $+0.5 \% \mathrm{C}$, we used the atmosphere $10 \% \mathrm{H}_{2}-\mathrm{N}_{2}$ with purity $5.0\left(\mathrm{O}_{2}\right.$ content $1 \mathrm{ppm}, \mathrm{H}_{2} \mathrm{O}$ content $3.2 \mathrm{ppm})$ and $6.0\left(\mathrm{O}_{2}\right.$ content $0.3 \mathrm{ppm}, \mathrm{H}_{2} \mathrm{O}$ content $0.5 \mathrm{ppm})$, respectively. Two different cooling rates, $10^{\circ} \mathrm{C} / \mathrm{min}$ and $50^{\circ} \mathrm{C} / \mathrm{min}$, were applied.

The data in Table 6 indicate that lower oxygen content in the atmosphere of purity 6.0 may shift the thermodynamic balance in inner microclimates toward reducing conditions more favourably than the atmosphere of purity 5.0. This resulted in efficient reduction and lower oxygen content in sintered compacts. The results also showed that the reduction 


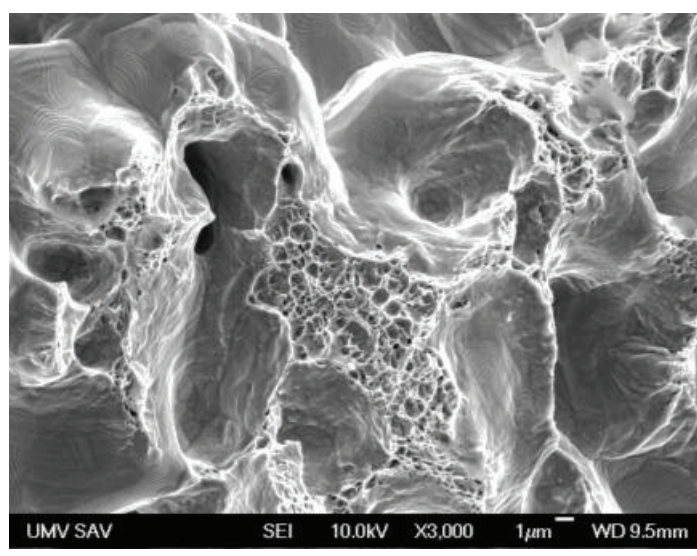

(a)

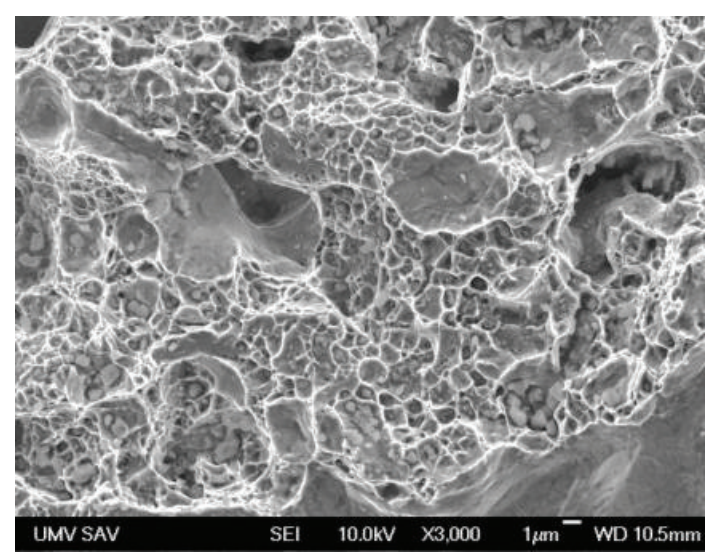

(b)

Figure 8: Fracture surface of the fractured AstCrM + 0.5\% C components with densities of (a) 6.5 and (b) $7.4 \mathrm{~g} / \mathrm{cm}^{3}$ sintered at $1120^{\circ} \mathrm{C}$ for $30 \mathrm{~min}$.

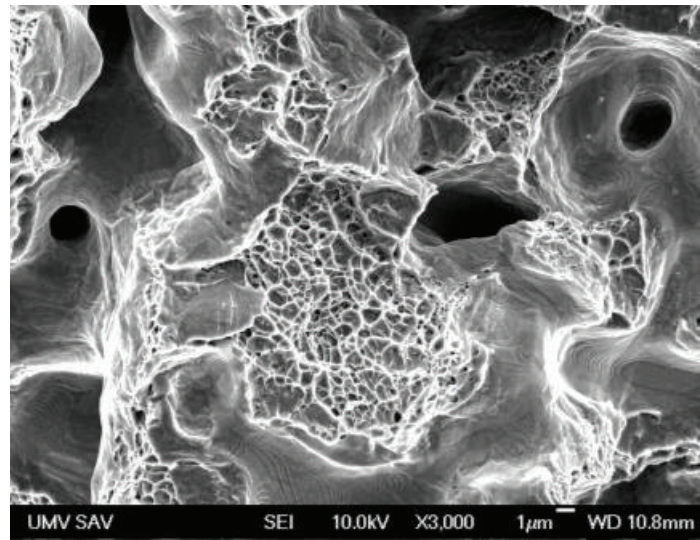

(a)

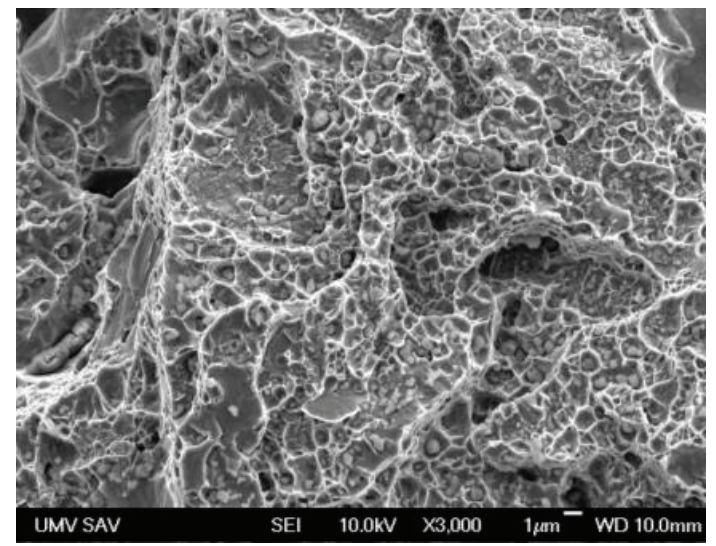

(b)

FIGURE 9: Fracture surface of the fractured AstCrM + 0.5\% C components with densities of (a) 6.5 and (b) $7.4 \mathrm{~g} / \mathrm{cm}^{3}$ sintered at $1200^{\circ} \mathrm{C}$ for $30 \mathrm{~min}$.

processes are influenced by density and cooling rate as well, even when sintered in the atmosphere of purity 6.0. For compacts with a density of $6.5 \mathrm{~g} / \mathrm{cm}^{3}$ cooled at a higher cooling rate, a relative decrease of oxygen content over the starting point achieved the value of $64 \%$; for densities of 6.8 and $7.1 \mathrm{~g} / \mathrm{cm}^{3}$, it was $54 \%$ and $37 \%$. The atmosphere purity does not have a significant effect on carbon content and the carbon loss over the starting point ranged from 14 to $18 \%$ for all applied conditions. The positive effect of a higher purity of the sintering atmosphere on reduction processes together with a faster cooling rate resulted in higher fracture strength values; see Table 6 .

3.5. Sintering in Nitrogen Atmosphere. After drying with liquid nitrogen, the AstCrM $+0.5 \% \mathrm{C}$ compacts with densities of $6.5,6.8$, and $7.1 \mathrm{~g} / \mathrm{cm}^{3}$ were sintered at 1120 and $1200^{\circ} \mathrm{C}$ for 30 min in pure $\mathrm{N}_{2}$-atmosphere with a dew point of $-68^{\circ} \mathrm{C}$.

Analyzing the spectra of $\mathrm{H}_{2} \mathrm{O}, \mathrm{CO}_{2}$, and $\mathrm{CO}$ contents in exhaust gas, see Figure 12, the differences for inert and reduction atmospheres used may be identified. The $\mathrm{H}_{2} \mathrm{O}$ curves exhibit only a small peak at 430 to $460^{\circ} \mathrm{C}$ that corresponds to the removal of chemically bonded water (hydroxides, hydrocarbonates, etc.). However, the amount of water vapour (the dew point from -32 to $-33^{\circ} \mathrm{C}$ ) is lower than for sintering in $10 \% \mathrm{H}_{2}-\mathrm{N}_{2}$ atmosphere (see Table 2(a)). There was registered a peak at $\sim 470^{\circ} \mathrm{C}$ characteristic for reduction of iron oxides by hydrogen. Similarly, the high-temperature peak at $\sim 1100^{\circ} \mathrm{C}$, which corresponds to interactions between the active gases in the system indicating further carbothermal reduction steps, has not been identified.

Small peaks on the CO curve in the range of $400-600^{\circ} \mathrm{C}$ are associated with decomposition of surface contaminations and graphite oxidation. The peaks above $\sim 800^{\circ} \mathrm{C}$ correspond to reduction of iron oxides that are in contact with graphite. Sharpness of the peaks decreases with density increasing, as in the case of nitrogen/hydrogen blends. A tendency of peaks shifting to higher temperatures with an increase in density was registered as well. For low density of $6.5 \mathrm{~g} / \mathrm{cm}^{3}$, there also 


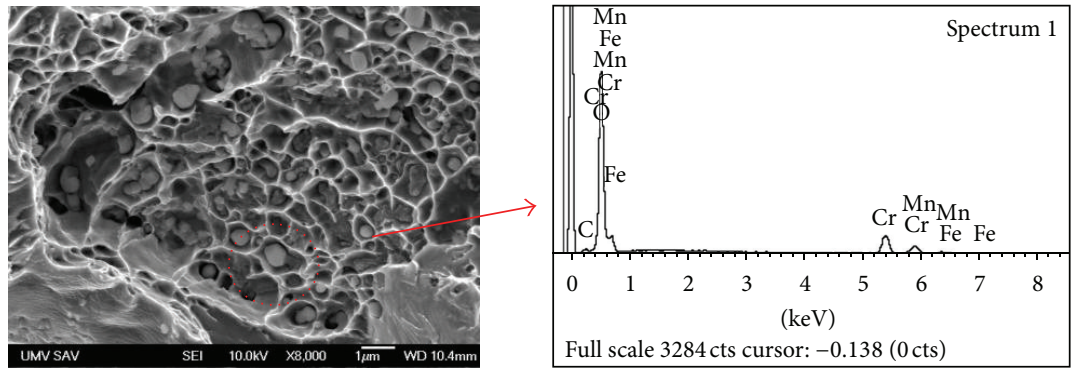

Figure 10: EDX analysis of oxides showed the presence of $34 \mathrm{wt} . \%$ of oxygen, $23 \mathrm{wt} . \%$ of chromium, and $11 \%$ of manganese and $32 \mathrm{wt} . \%$ of iron.

TABLE 5: Effect of heating and cooling rates on oxygen and carbon contents and fracture strength of AstCrM $+0.5 \% \mathrm{C}$ material sintered at 1120 and $1200^{\circ} \mathrm{C}$ in relation to density.

\begin{tabular}{|c|c|c|c|c|c|}
\hline Density level $\left(\mathrm{g} / \mathrm{cm}^{3}\right)$ & Sintering temperature $\left({ }^{\circ} \mathrm{C}\right)$ & Heating/cooling rate $\left({ }^{\circ} \mathrm{C} / \mathrm{min}\right)$ & $\mathrm{O}_{2}(\%)$ & $\mathrm{C}(\%)$ & $R_{\mathrm{FR}}(\mathrm{MPa})$ \\
\hline \multirow{6}{*}{6.5} & \multirow{4}{*}{1120} & $10 / 10$ & 0.114 & 0.41 & 466 \\
\hline & & $50 / 10$ & 0.117 & 0.41 & 552 \\
\hline & & $10 / 50$ & 0.098 & 0.42 & 640 \\
\hline & & $50 / 50$ & 0.110 & 0.415 & 562 \\
\hline & \multirow{2}{*}{1200} & $10 / 10$ & 0.061 & 0.36 & 538 \\
\hline & & $10 / 50$ & 0.025 & 0.37 & 838 \\
\hline \multirow{6}{*}{6.8} & \multirow{4}{*}{1120} & $10 / 10$ & 0.118 & 0.41 & 566 \\
\hline & & $50 / 10$ & 0.120 & 0.41 & 620 \\
\hline & & $10 / 50$ & 0.097 & 0.42 & 754 \\
\hline & & $50 / 50$ & 0.108 & 0.42 & 929 \\
\hline & \multirow{2}{*}{1200} & $10 / 10$ & 0.076 & 0.35 & 725 \\
\hline & & $10 / 50$ & 0.027 & 0.37 & 945 \\
\hline \multirow{6}{*}{7.1} & \multirow{4}{*}{1120} & $10 / 10$ & 0.142 & 0.42 & 719 \\
\hline & & $50 / 10$ & 0.145 & 0.43 & 720 \\
\hline & & $10 / 50$ & 0.133 & 0.43 & 929 \\
\hline & & $50 / 50$ & 0.108 & 0.42 & 889 \\
\hline & \multirow{2}{*}{1200} & $10 / 10$ & 0.088 & 0.38 & 894 \\
\hline & & $10 / 50$ & 0.068 & 0.38 & 966 \\
\hline
\end{tabular}

TABLE 6: Effect of atmosphere purity and cooling rate on oxygen and carbon contents in AstCrM $+0.5 \% \mathrm{C}$ material sintered at $1120^{\circ} \mathrm{C}$ for $30 \mathrm{~min}$ in relation to density.

\begin{tabular}{|c|c|c|c|c|c|}
\hline Density level $\left(\mathrm{g} / \mathrm{cm}^{3}\right)$ & Atmosphere purity & Cooling rate $\left({ }^{\circ} \mathrm{C} / \mathrm{min}\right)$ & $\mathrm{O}_{2}(\%)$ & $\mathrm{C}(\%)$ & $R_{\mathrm{FR}}(\mathrm{MPa})$ \\
\hline \multirow{4}{*}{6.5} & \multirow{2}{*}{6.0} & 50 & 0.070 & 0.425 & 680 \\
\hline & & 10 & 0.095 & 0.41 & 559 \\
\hline & \multirow{2}{*}{5.0} & 50 & 0.098 & 0.42 & 640 \\
\hline & & 10 & 0.114 & 0.41 & 466 \\
\hline \multirow{4}{*}{6.8} & \multirow{2}{*}{6.0} & 50 & 0.090 & 0.43 & 788 \\
\hline & & 10 & 0.100 & 0.41 & 642 \\
\hline & \multirow{2}{*}{5.0} & 50 & 0.097 & 0.42 & 754 \\
\hline & & 10 & 0.118 & 0.41 & 566 \\
\hline \multirow{4}{*}{7.1} & \multirow{2}{*}{6.0} & 50 & 0.125 & 0.43 & 948 \\
\hline & & 10 & 0.142 & 0.42 & 801 \\
\hline & \multirow{2}{*}{5.0} & 50 & 0.133 & 0.43 & 929 \\
\hline & & 10 & 0.142 & 0.42 & 729 \\
\hline
\end{tabular}




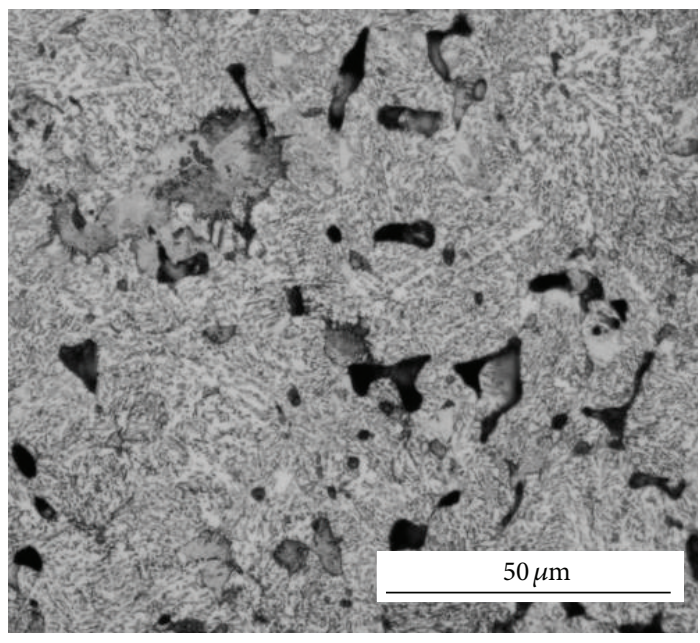

(a)

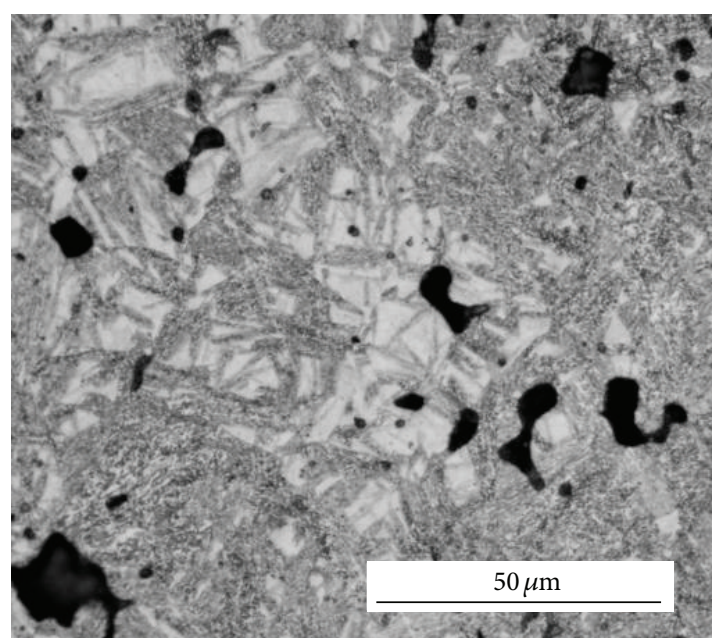

(b)

Figure 11: Microstructure of the AstCrM + 0.5\% C components sintered at $1200^{\circ} \mathrm{C}$ for $30 \mathrm{~min}$ (a) prevalent upper bainitic when cooled at $10^{\circ} \mathrm{C} / \mathrm{min}$ and upper/lower bainite mixture when cooled at $50^{\circ} \mathrm{C} / \mathrm{min}$.

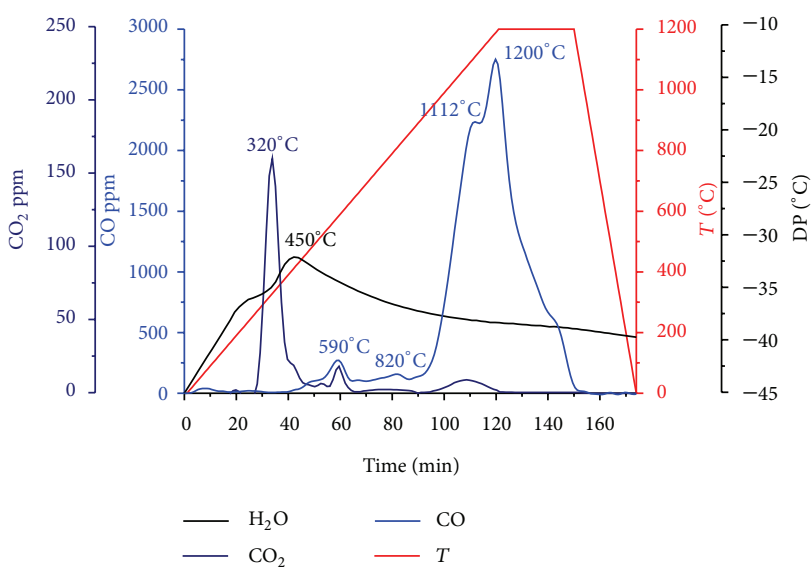

(a) $6.5 \mathrm{~g} / \mathrm{cm}^{3}$

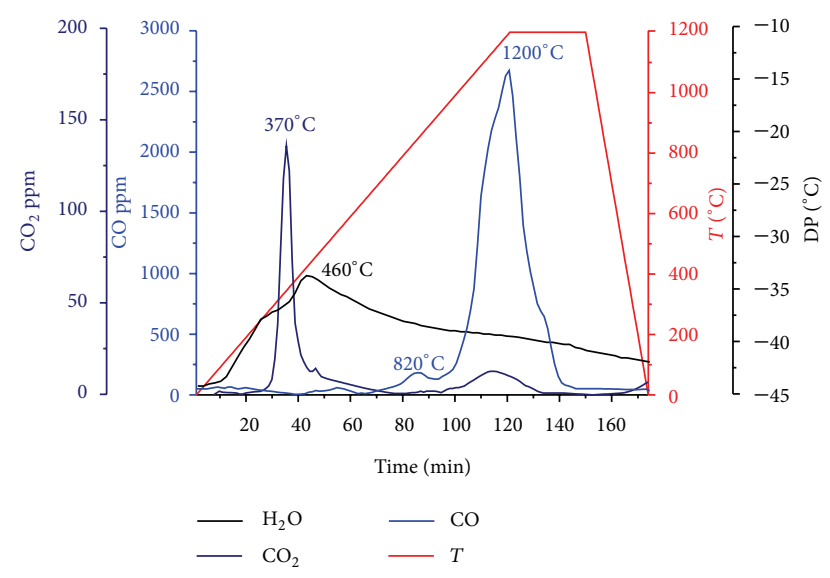

(b) $6.8 \mathrm{~g} / \mathrm{cm}^{3}$

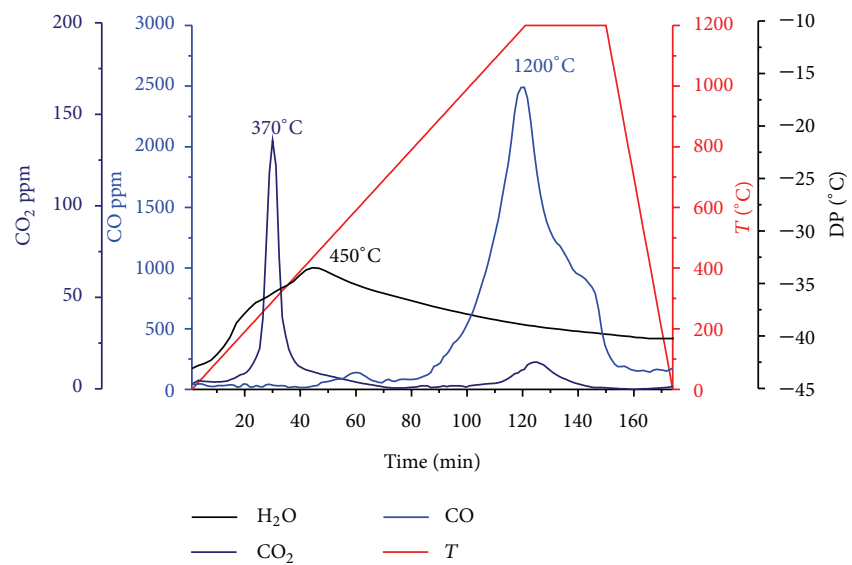

(c) $7.1 \mathrm{~g} / \mathrm{cm}^{3}$

FIgURE 12: (a)-(c) Spectra of processing gas composition during sintering of the AstCr $+0.5 \% \mathrm{C}$ components with densities of $6.5,6.8$, and $7.1 \mathrm{~g} / \mathrm{cm}^{3}$ at $1200^{\circ} \mathrm{C}$ for $30 \mathrm{~min}$ in $\mathrm{N}_{2}$ atmosphere. 
TABLE 7: Effect of sintering in $\mathrm{N}_{2}$ atmosphere on oxygen and carbon content in the AstCrM $+0.5 \% \mathrm{C}$ at $1120^{\circ} \mathrm{C}$ and $1200^{\circ} \mathrm{C}$ for 30 min (with heating rate of $10^{\circ} \mathrm{C} / \mathrm{min}$ and cooling rates of $50^{\circ} \mathrm{C} / \mathrm{min}$ ) in relation to density.

\begin{tabular}{lcccc}
\hline Density level $\left(\mathrm{g} / \mathrm{cm}^{3}\right)$ & Sintering temperature $\left({ }^{\circ} \mathrm{C}\right)$ & $\mathrm{O}_{2}(\%)$ & $\mathrm{C}(\%)$ & $R_{\mathrm{FR}}(\mathrm{MPa})$ \\
\hline \multirow{2}{*}{6.5} & 1120 & 0.125 & 0.410 & 537 \\
& 1200 & 0.044 & 0.360 & 803 \\
\hline \multirow{2}{*}{6.8} & 1120 & 0.122 & 0.415 & 700 \\
& 1200 & 0.041 & 0.366 & 880 \\
\hline \multirow{2}{*}{7.1} & 1120 & 0.136 & 0.430 & 815 \\
& 1200 & 0.093 & 0.390 & 943 \\
\hline
\end{tabular}

TABLE 8: Oxygen and carbon contents in the AstCrM $+0.5 \% \mathrm{C}$ components sintered at $1120^{\circ} \mathrm{C}$ in a graphite container using $\mathrm{N}_{2}$ atmosphere and in a stainless container using $\mathrm{N}_{2}$ and $10 \% \mathrm{H}_{2}-$ $\mathrm{N}_{2}$ atmospheres.

\begin{tabular}{lccc}
\hline Sintering condition & $\mathrm{O}_{2}(\%)$ & $\mathrm{C}(\%)$ & $R_{\mathrm{FR}}(\mathrm{MPa})$ \\
\hline Graphite container $/ \mathrm{N}_{2}$ atmosphere & 0.105 & 0.44 & 721 \\
Stainless container $/ \mathrm{N}_{2}$ atmosphere & 0.122 & 0.42 & 700 \\
Stainless container $/ 10 \% \mathrm{H}_{2}-\mathrm{N}_{2}$ & 0.097 & 0.42 & 754 \\
\hline
\end{tabular}

exists a small peak at $\sim 1112^{\circ} \mathrm{C}$ corresponding to reduction of surface chromium-rich oxides and oxides from internal volumes communicating with the flowing atmosphere.

Comparing the $\mathrm{CO}$ profiles for sintering in pure nitrogen and $\mathrm{H}_{2}$ containing atmosphere (see Figure 5), it is evident that the peak at $\sim 1112^{\circ} \mathrm{C}$ for density of $6.5 \mathrm{~g} / \mathrm{cm}^{3}$ is less pronounced and the peak at $\sim 1120^{\circ} \mathrm{C}$ for the density of $6.8 \mathrm{~g} / \mathrm{cm}^{3}$ does not appear during sintering in $\mathrm{N}_{2}$-atmosphere at all. It enables assuming that the peak at $\sim 1120^{\circ} \mathrm{C}$ is the result of $\mathrm{H}_{2}$ and $\mathrm{CO}_{2}$ interaction inside the sintered component. The peak with a maximum at $1200^{\circ} \mathrm{C}$ is associated with the carbothermal reduction of thermodynamically stable surface spinel $\mathrm{Cr}-\mathrm{Mn}$ rich oxides and mixed internal oxides. Small observed $\mathrm{CO}_{2}$ peaks have comparable features as in the case of hydrogencontaining atmosphere.

Comparing the values in Tables 4 and 7 , it can be seen that differences in carbon content resulting from sintering in $\mathrm{N}_{2}$ atmosphere and in $\mathrm{H}_{2}$ containing atmosphere are minimal. A tendency to increase in carbon content for specimens with higher density for both types of atmospheres is seen. Similar is also a tendency to a decreased carbon content for higher sintering temperature.

Due to a higher amount of oxides, the fracture strength after sintering in $\mathrm{N}_{2}$ atmosphere (see Table 7) is lower than for sintering in reducing atmosphere (see Table 4).

3.5.1. Sintering in a Graphite Container in $\mathrm{N}_{2}$ Atmosphere. The graphite container was used to increase reduction potential of carbon during sintering in $\mathrm{N}_{2}$-atmosphere. The AstCrM + $0.5 \% \mathrm{C}$ compacts of density $6.8 \mathrm{~g} / \mathrm{cm}^{3}$ were sintered at $1120^{\circ} \mathrm{C}$ for $30 \mathrm{~min}$ in a graphite container in $\mathrm{N}_{2}$-atmosphere of purity 5.0. Comparing the oxygen content with that for sintering in a stainless container in both $\mathrm{N}_{2}$ and $\mathrm{H}_{2}$ containing atmospheres (see Table 8) shows that it is slightly higher than after sintering in a stainless container using $\mathrm{H}_{2}$ containing atmosphere, but lower than for the sintering in $\mathrm{N}_{2}$-atmosphere. At the same time the carbon content slightly increased during sintering in graphite container. Fracture strength values obtained are in a good agreement with the oxygen content.

3.6. Effect of Carbon Content Addition. The mixtures of the AstCrM powder with an addition of $0.5,0.6$, and 0.8 wt.\% graphite were compacted to the density of $6.8 \mathrm{~g} / \mathrm{cm}^{3}$ and isothermally sintered at 1120 and $1200^{\circ} \mathrm{C}$ for $30 \mathrm{~min}$ in $10 \%$ $\mathrm{H}_{2}-90 \% \mathrm{~N}_{2}$ atmosphere (purity of 5.0).

Analyzing the profiles of $\mathrm{H}_{2} \mathrm{O}, \mathrm{CO}_{2}$, and $\mathrm{CO}$ contents and peak positions presented in Figure 13 and summarized in Table 9, it is evident that the carbon content determines the shape, temperature, and intensity of the CO peaks. The first $\mathrm{CO}$ peak, related to the iron oxides reduction by graphite in $\mathrm{Fe}-\mathrm{C}$ contacts, was recorded at $820^{\circ} \mathrm{C}$ for $0.5 \% \mathrm{C}$; for $0.6 \% \mathrm{C}$ it is shifted to $810^{\circ} \mathrm{C}$, and for $0.8 \% \mathrm{C}$ to $780^{\circ} \mathrm{C}$. The second $\mathrm{CO}$ peak associated with the carbothermal reduction of stable surface chromium-rich oxides and iron oxides from the internal pores was recorded at $1120^{\circ} \mathrm{C}$ for $0.5 \% \mathrm{C}$; for $0.6 \%$ $\mathrm{C}$ it was shifted to $1100^{\circ} \mathrm{C}$, and for $0.8 \% \mathrm{C}$ to $1074^{\circ} \mathrm{C}$.

Dew point peaks at high temperature are rather wide, and hence the peak temperature shows minimal differences in relation to carbon content. $\mathrm{CO}_{2}$ peaks seem to be identical for materials with and without carbon addition. Low-temperature $\mathrm{H}_{2} \mathrm{O}$ peak has a maximum at $470^{\circ} \mathrm{C}$ independently of graphite addition as it corresponds to the reduction of iron oxide layer by hydrogen. The $\mathrm{CO}_{2}$ peak at $320^{\circ} \mathrm{C}$ was also observed in all cases, confirming that it is connected to a carbonate/hydrocarbonate decomposition and not to graphite oxidation. Some contributions from the decomposition of a small amount of the present lubricant can be expected as well.

According to oxygen and carbon contents listed in Table 10, it is shown that an increase in graphite resulted in a decrease of oxygen content by $44-51 \%$ during sintering at $1120^{\circ} \mathrm{C}$ and by $80-86 \%$ at $1200^{\circ} \mathrm{C}$. At the same time, the carbon content decreases by $16 \%$ for sintering at $1120^{\circ} \mathrm{C}$ and by $30 \%$ at $1200^{\circ} \mathrm{C}$. The mass changes correspond to recorded changes in oxygen and carbon contents.

The fracture strength values exhibited a decreasing tendency with an increasing carbon content. The highest strength was attested in AstCrM $+0.5 \% \mathrm{C}$ material and the 
TABLE 9: Temperatures of the $\mathrm{H}_{2} \mathrm{O}, \mathrm{CO}_{2}$, and $\mathrm{CO}$ peaks in relation to graphite addition; AstCrM $+\mathrm{C}$ material with the density of $6.8 \mathrm{~g} / \mathrm{cm}^{3}$ sintered at $1200^{\circ} \mathrm{C}$.

\begin{tabular}{|c|c|c|c|c|c|c|c|c|}
\hline \multirow{2}{*}{ Graphite addition (wt.\%) } & \multicolumn{3}{|c|}{$\mathrm{H}_{2} \mathrm{O}$ peak } & \multirow{2}{*}{$\begin{array}{c}\mathrm{CO}_{2} \text { peak } \\
1 \text { st }\left({ }^{\circ} \mathrm{C}\right)\end{array}$} & \multicolumn{4}{|c|}{ CO peak } \\
\hline & 1st $\left({ }^{\circ} \mathrm{C}\right)$ & 2nd $\left({ }^{\circ} \mathrm{C}\right)$ & $3 \mathrm{rd}\left({ }^{\circ} \mathrm{C}\right)$ & & 1 st $\left({ }^{\circ} \mathrm{C}\right)$ & 2nd $\left({ }^{\circ} \mathrm{C}\right)$ & 3rd $\left({ }^{\circ} \mathrm{C}\right)$ & 4 th $\left({ }^{\circ} \mathrm{C}\right)$ \\
\hline 0.5 & 180 & 470 & 1075 & 320 & 500 & 820 & 1120 & 1200 \\
\hline 0.6 & 182 & 470 & 1080 & 320 & 500 & 810 & 1100 & 1200 \\
\hline 0.8 & 170 & 470 & 1105 & 320 & 490 & 780 & 1074 & 1200 \\
\hline
\end{tabular}

TABLE 10: Mass change and oxygen and carbon contents in AstCrM $+\mathrm{C}$ material with density of $6.8 \mathrm{~g} / \mathrm{cm}^{3}$ sintered at $1200^{\circ} \mathrm{C}$ in relation to graphite addition.

\begin{tabular}{lcccccc}
\hline Graphite addition (wt.\%) & Temperature $\left({ }^{\circ} \mathrm{C}\right)$ & Sintered density $\left(\mathrm{g} / \mathrm{cm}^{3}\right)$ & Mass change $(\%)$ & $\mathrm{O}_{2}(\%)$ & $\mathrm{C}(\%)$ & $R_{\mathrm{FR}}(\mathrm{MPa})$ \\
\hline 0.0 & 1200 & 6.78 & -0.05 & 0.161 & - & 128 \\
\hline \multirow{2}{*}{0.5} & 1120 & 6.80 & -0.20 & 0.097 & 0.42 & 754 \\
& 1200 & 6.89 & -0.32 & 0.039 & 0.34 & 945 \\
\hline \multirow{2}{*}{0.6} & 1120 & 6.78 & -0.24 & 0.110 & 0.51 & 690 \\
& 1200 & 6.80 & -0.35 & 0.027 & 0.42 & 847 \\
\multirow{2}{*}{0.8} & 1120 & 6.76 & -0.29 & 0.110 & 0.68 & 249 \\
& 1200 & 6.79 & -0.36 & 0.023 & 0.56 & 405 \\
\hline
\end{tabular}

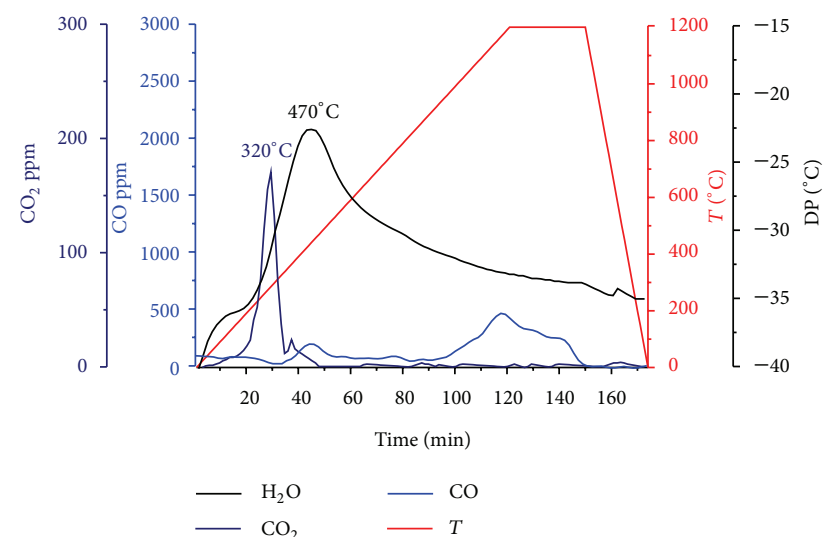

(a) Without graphite addition

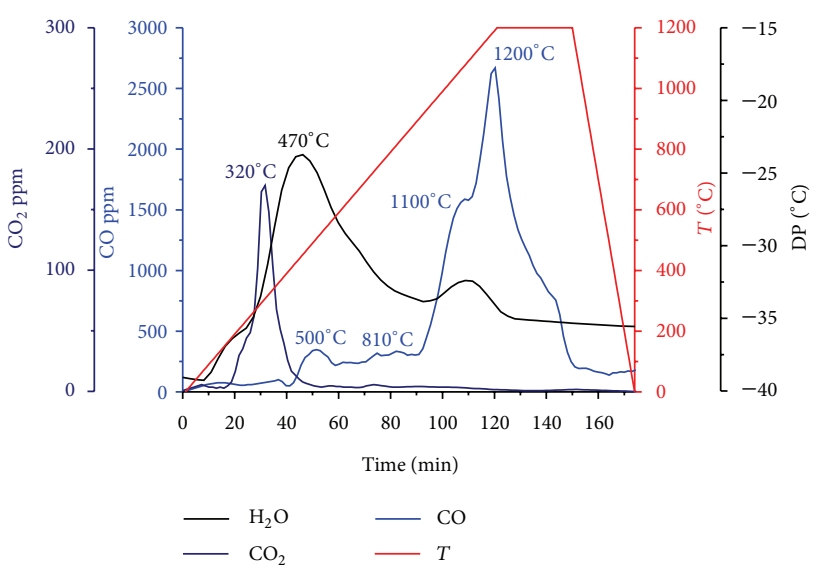

(c) $0.6 \%$ graphite addition

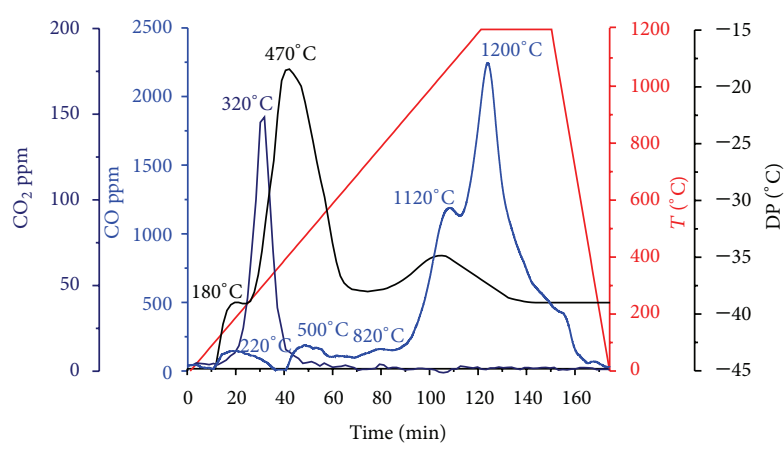

$-\mathrm{H}_{2} \mathrm{O} \quad \mathrm{CO}$

(b) $0.5 \%$ graphite addition

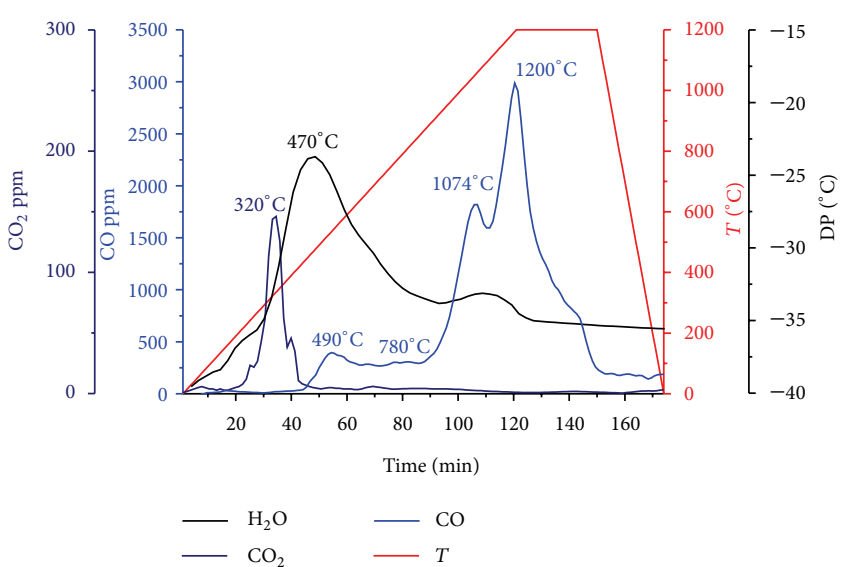

(d) $0.8 \%$ graphite addition

FIGURE 13: (a)-(d) Spectra of sampled processing gas composition during sintering of AstCrM components without carbon and with 0.5, 0.6, and $0.8 \mathrm{wt} . \%$ graphite addition at $1200^{\circ} \mathrm{C}$ for $30 \mathrm{~min}$ in $10 \% \mathrm{H}_{2}-\mathrm{N}_{2}$ atmosphere. 
lowest for AstCrM $+0.8 \% \mathrm{C}$. That is caused by a higher carbon content as is eutectoid content of $0.35 \%$ at $780^{\circ} \mathrm{C}[37,38]$ for the $\mathrm{Fe}-3 \% \mathrm{Cr}-\mathrm{C}$ system.

This is registered for AstCrM $+0.5 \% \mathrm{C}$ material sintered at $1120^{\circ} \mathrm{C}$ and for all admixed with 0.6 and $0.8 \% \mathrm{C}$ compacts; see Table 10 .

Therefore, the decrease in the fracture strength is a result of the cementite film formation at grain boundaries with subsequent intergranular failure; see Figure 14 for the AstCrM + $0.8 \%$ C material.

\section{Discussion}

Progress in reduction processes in terms of used processing conditions (green density, sintering temperature, heating and cooling rates, type and purity of sintering atmosphere, and carbon content) has been evaluated by oxygen and carbon contents in sintered material. Effect of residual oxide contamination on material performance was analysed through fracture strength of sintered components.

Information obtained regarding achieved oxygen content and the corresponding fracture strengths for processing conditions applied in this study are summarized in Figures 15 and 16.

4.1. Oxygen Content and Processing Conditions. The highest decrease of the oxygen content in the AstCrM $+0.5 \% \mathrm{C}$ material, more than by $75 \%$, that is, $0.025-0.034 \% \mathrm{O}_{2}$, was achieved for low-density components $\left(6.5\right.$ and $\left.6.8 \mathrm{~g} / \mathrm{cm}^{3}\right)$ sintered at $1200^{\circ} \mathrm{C}$ in $10 \% \mathrm{H}_{2}-\mathrm{N}_{2}$ (5.0) atmosphere using cooling rate $50^{\circ} \mathrm{C} / \mathrm{min}$, while sintering at $1120^{\circ} \mathrm{C}$ resulted in a lower decrease of oxygen content, by $75-50 \%$, that is, $0.05-$ $0.099 \% \mathrm{O}_{2}$, for densities of 6.5 and $6.8 \mathrm{~g} / \mathrm{cm}^{3}$.

The use of graphite container and $\mathrm{N}_{2}$-atmosphere for sintering of components density of 6.5 and $6.8 \mathrm{~g} / \mathrm{cm}^{3}$ at $1120^{\circ} \mathrm{C}$ with cooling at $10^{\circ} \mathrm{C} / \mathrm{min}$ resulted in the decrease of oxygen content by $38-50 \%$ which represented $0.10-0.123 \%$ $\mathrm{O}_{2}$.

The decrease in the oxygen content by $25-38 \%(0.123-$ $0.148 \% \mathrm{O}_{2}$ ) corresponds to components density of $7.1 \mathrm{~g} / \mathrm{cm}^{3}$ sintered at $1120^{\circ} \mathrm{C}$ in both atmospheres $10 \% \mathrm{H}_{2}-\mathrm{N}_{2}$ (5.0) and $\mathrm{N}_{2}$ (5.0) and both cooling rates; higher decrease of oxygen content corresponds to higher cooling rate.

The lowest values of decrease in oxygen content, less than by $25 \%$ (i.e., oxygen content higher than $0.123 \%$ ), was recorded for high-density components $\left(7.4 \mathrm{~g} / \mathrm{cm}^{3}\right)$ processed under all conditions used in this study. It should be noted that such a result is assumed to be connected to the massive oxide transformation from the iron-based to more chromium-based oxides during annealing before repressing. Additionally, such a high density results in pore enclosure inside the compact, meaning that there is limited interaction with the processing atmosphere. Poor microclimate inside the component leads to unsatisfactory surface oxides reduction. Higher oxygen content causes weakening of interfaces with oxides and therefore poor final strength properties.
4.2. Fracture Strength and Oxygen Content. Generally, as it is also evident from data in Figure 16, the strength properties of sintered steels exposed to the same loading conditions are controlled by the quality of interparticle necks (size, microstructure, and oxide contamination) and matrix microstructure, or more precisely, by micromechanical interactions of pores and microstructure of matrix surrounding the pores.

The highest values of the fracture strength, over $950 \mathrm{MPa}$, were obtained in materials with densities of 6.8 and $7.1 \mathrm{~g} / \mathrm{cm}^{3}$ sintered at $1200^{\circ} \mathrm{C}$, which means that the main role is played by a sufficient elimination of oxides from interparticle necks, sufficiently low porosity, rounded pores, and strength bainitic microstructure. The lowest values of fracture strength, 466 to $562 \mathrm{MPa}$, belong to the low-density specimens sintered at $1120^{\circ} \mathrm{C}$ when, even at relatively low oxygen content of $0.098-0.125 \%$, the negative impact of larger amount of pores dominates. The lowest fracture strength of $249 \mathrm{MPa}$ is a result of grain boundaries weakened by carbidic phase at the carbon content higher than $\sim 0.45 \%$ as well as sintering at $1120^{\circ} \mathrm{C}$.

Hence, observed trends in the oxygen content development and resulting mechanical properties can be summarised as follows. Low-density components (up to $6.8 \mathrm{~g} / \mathrm{cm}^{3}$ ) can be sintered to nearly oxide-free state, even at $1120^{\circ} \mathrm{C}$ in hydrogen containing atmospheres, even at low purity (5.0). When it comes to the specimens with higher density $\left(>7.0 \mathrm{~g} / \mathrm{cm}^{3}\right)$, lower porosity results in restricted replenishment of the atmosphere in the local "microclimates" inside the pores and the sintering atmosphere on the surface of the compact, especially deep in the compact cores, resulting in shifting of the conditions in the pores to less reducing or even oxidising ones in comparison with lower-density compacts. As a result, oxide transformation/formation processes take place, resulting in intensive oxide formation and thus lower mechanical properties. Results also indicate that in case of repressing, special attention must be devoted during annealing treatment in order to avoid massive oxide transformation into more stable oxides - and hence interface degradationresulting in weak interparticle necks. Therefore, importance of the sintering atmosphere purity and flow during initial stages of sintering is higher in the case of the high-density component $>7.0 \mathrm{~g} / \mathrm{cm}^{3}$ due to the risk of oxide transformation. This is also evident in the present results, as rather low flow rate used resulted in higher oxygen content in the case of high-density components observed in other studies [39]. Results also indicate that full reduction of the oxides needs temperatures above $1200^{\circ} \mathrm{C}$.

\section{Conclusions}

The results of the continuous monitoring of the sintering atmosphere composition confirmed that oxide reduction during sintering of Cr-alloyed water-atomized powder steels occurs in two temperature intervals. During heating in temperature interval of $300-500^{\circ} \mathrm{C}$, reduction of surface iron oxides by hydrogen from sintering atmosphere occurs. Carbothermal reduction connected to $\mathrm{CO}$ formation starts above $750^{\circ} \mathrm{C}$. The reduction of stable surface Fe-based mixed 


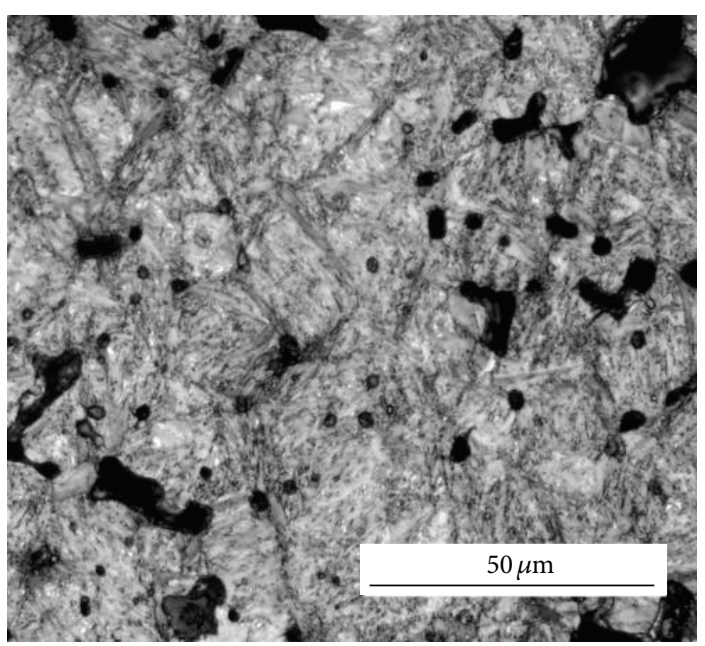

(a)

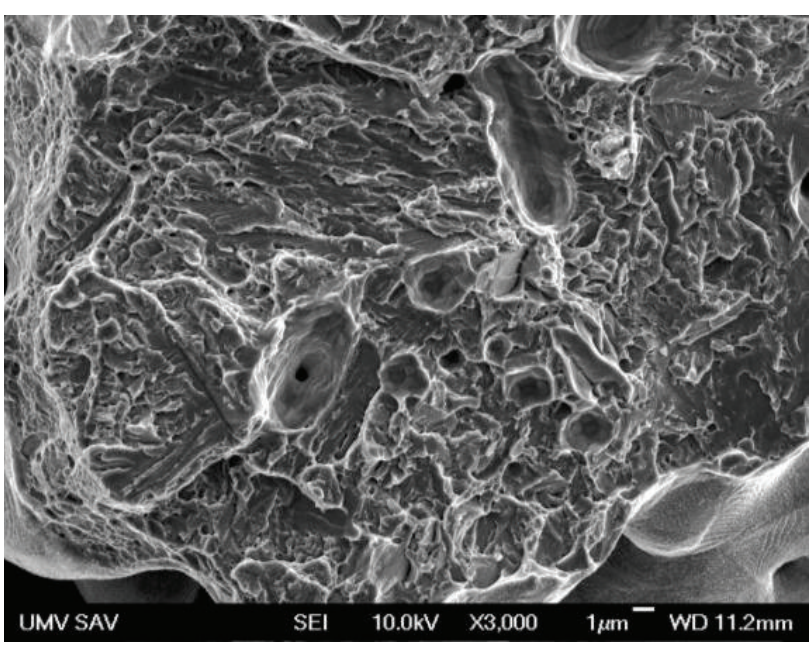

(b)

FIgURE 14: Microstructure and fracture surface of AstCrM $+0.8 \% \mathrm{C}$ material sintered at $1200^{\circ} \mathrm{C}$.

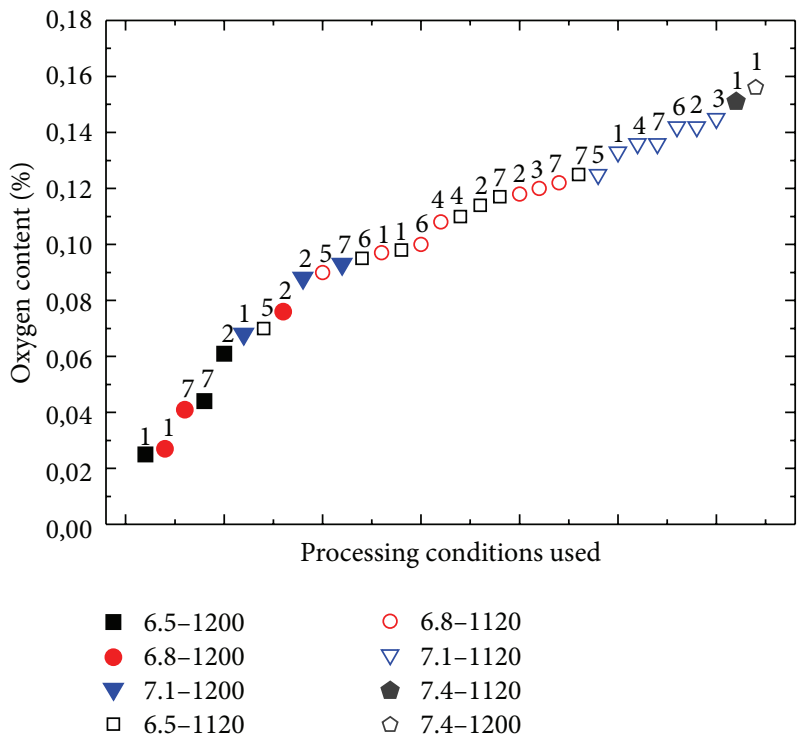

Figure 15: Oxygen content increasing in AstCrM-C alloys in relation to the processing conditions used.

oxides, where $\mathrm{Mn}$ and $\mathrm{Cr}$ may be present, but in diluted form, takes place above $1000^{\circ} \mathrm{C}$. Stable $\mathrm{Mn}$-Cr-rich surface oxides and internal oxides are reduced at about $1200^{\circ} \mathrm{C}$.

Oxide reduction processes are more advanced after sintering at a higher temperature $\left(1200^{\circ} \mathrm{C}\right)$ which results in lower oxygen content. Evidently, the use of $1200^{\circ} \mathrm{C}$ as compared to $1120^{\circ} \mathrm{C}$ represents a more favourable condition for oxide reduction not only thermodynamically but also kinetically. This has also been recently confirmed in a work by Danninger [35].

The oxygen content increases with density of material sintered at both temperatures of 1120 and $1200^{\circ} \mathrm{C}$. With a green density increasing, the reduction processes become more difficult due to poor interaction of the atmosphere

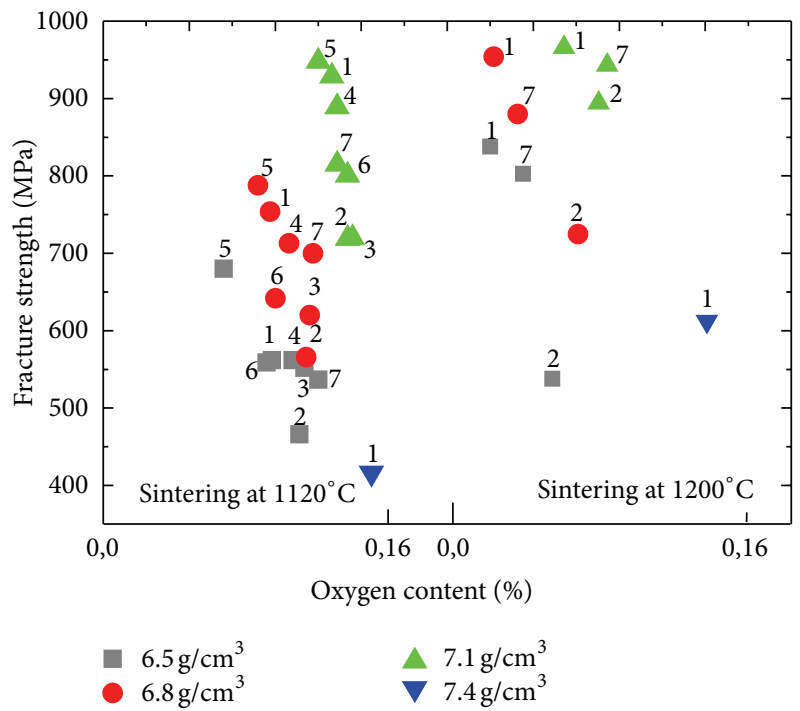

FIGURE 16: Fracture strength in relation to oxygen content achieved at processing condition used.

inside the pores of the compact- "microclimate"-with the sintering atmosphere on the compact surface, and the reduction processes are shifted to higher temperatures.

Faster heating rate $\left(50^{\circ} \mathrm{C} / \mathrm{min}\right)$ has a negative effect on reduction processes due to insufficient "blow off" of reduction gas products. Hence, higher flow has to be combined with the corresponding flow rate, high enough to assure full removal of reduction products. Deterioration of the purity of the atmosphere in the inner microvolumes of compacts shifts the thermodynamical equilibrium towards oxidation, and it results in enclosure of residual oxides inside particle necks. The consequence of oxide enclosure is higher oxygen content and lower mechanical properties of the compacts.

Using higher cooling rate can prevent reoxidation of material during the cooling stage. The results confirmed 
the advantage of hydrogen containing atmosphere when hydrogen reduces iron oxide layer early during the heating stage. Hydrogen also contributes to the increasing of reduction ability of microclimates within compacts at high temperatures through water reaction.

The results confirmed that different carbon contents has a minor effect on reduction processes, but, as it is well known, the carbon content has a significant effect on microstructure. To achieve the desired performance, the carbon content in AstCrM-C material has to be below eutectoid content in as-sintered state. The optimal carbon content for AstCrM is $0.40-0.45 \mathrm{wt} . \%$; a higher content negatively impacts the strength properties. As previously reported by Ortiz and Castro [28], PM steels in this alloy system, with carbon contents higher than $0.45 \mathrm{wt} . \%$, are hypereutectoid.

\section{Acknowledgment}

The authors are grateful for the financial support of Slovak National Grant Agency (Project VEGA 2/0153/12).

\section{References}

[1] S. Berg and B. Maroli, "Properties obtained by chromium contained material," in Advances in Powder Metallurgy and Particulate Materials, V. Arnhold, C. L. Chu, W. F. Jandeska Jr., and H. I. Sanderow, Eds., part 8, pp. 1-14, MPIF, Princeton, NJ, USA, 2002.

[2] A. Bergmark, J. Andersson, and S. Bengston, "Chromium pre-alloyed PM steels for high structural performance," in Proceedings of the EURO PM2005 Conference, vol. 1, pp. 157-152, EPMA, Prague, Czech Republic, 2005.

[3] U. Engstrom, D. Milligan, and A. Klekovkin, "Mechanical properties of high performance chromium materials," in Advances in Powder Metallurgy \& Particulates Materials, vol. 7, pp. 21-32, MPIF, San Diego, Calif, USA, 2004.

[4] A. Bergmark, O. Bergman, and L. Alzati, "Pre-alloyed chromium materials for highly fatigue loaded PM parts," in Advanced in Powder Metallurgy \& Particulates Material, part 2, pp. 13-21, MPIF, Chicago, Ill, USA, 2004.

[5] M. Hull, "Astaloy CrM new generation powder from Höganäs," Powder Metallurgy, vol. 41, no. 4, pp. 232-233, 1998.

[6] H. Karlsson, Role of surface oxides in sintering of chromiumalloyed steel powder [Ph.D. thesis], Chalmers University of Technology, Goteborg, Sweden, 2005.

[7] E. Hryha and L. Nyborg, "Oxide transformation during sintering of pre-alloyed water atomized steel powder," in Proceedings of the PM2010 Powder Metallurgy World Congress \& Exhibition, vol. 2, pp. 267-274, Florence, Italy, 2010.

[8] H. Karlsson, L. Nyborg, and S. Berg, "Surface interaction during sintering of water-atomized pre-alloyed steel powder," in Proceedings of the World Congress \& Exhibition on Powder Metallurgy, vol. 2, pp. 22-23, EPMA, Vienna, Austria, 2004.

[9] E. Hryha, C. Gierl, L. Nyborg, H. Danninger, and E. Dudrova, "Surface composition of the steel powders pre-alloyed with manganese," Applied Surface Science, vol. 256, no. 12, pp. 39463961, 2010.

[10] E. Hryha, L. Nyborg, and S. Bengston, "Surface analysis of prealloyed with manganese steel powder," in Proceedings of the PM2010 World Congress and Exhibition, vol. 2, pp. 169-174, EPMA, Florence, Italy, 2010.
[11] D. Chasoglou, E. Hryha, and L. Nyborg, "Effect of sintering atmosphere on the transformation of surface oxides during the sintering of chromium alloyed steels," Powder Metallurgy Progress, vol. 9, no. 3, pp. 141-147, 2009.

[12] D. Chasoglou, E. Hryha, and L. Nyborg, "Surface interactions during sintering of chromium-alloyed PM steels in different atmospheres," in Proceedings of the PM2010 World Congress and Exhibition, vol. 2, pp. 45-52, EPMA, Florence, Italy, 2010.

[13] O. Bergman, B. Lindqvist, and S. Bengtsson, "Influence of sintering parameters on the mechanical performance of PM steels pre-alloyed with chromium," Materials Science Forum, vol. 534-536, no. 1, pp. 545-548, 2007.

[14] O. Bergman, Study of oxide reduction and nitrogen uptake in sintering of chromium-alloyed steel powder [Licentiate Thesis], 2008.

[15] S. C. Mitchell and A. Cias, "Carbothermic reduction of oxides during nitrogen sintering of manganese and chromium steels," Powder Metallurgy Progress, vol. 4, no. 3, pp. 132-142, 2004.

[16] M. Youseffi, S. C. Mitchell, A. S. Wronski, and A. Cias, "Sintering, microstructure, and mechanical properties of PM manganese-molybdenum steels," Powder Metallurgy, vol. 43, no. 4, pp. 353-358, 2000.

[17] E. Hryha, Fundamental study of Mn containing PM steels with alloying method of both premix and pre-alloy [Ph.D. thesis], IMR SAS, Košice, Slovakia, 2007.

[18] E. Hryha, L. Cajkova, and E. Dudrova, "Study of reductionoxidation processes in Cr-Mo pre alloyed steels during sintering by continuous atmosphere monitoring," Powder Metallurgy Progress, vol. 7, no. 4, pp. 181-189, 2008.

[19] E. Hryha and E. Dudrova, "The sintering behaviour of FeMn powder system, correlation between thermodynamics and sintering process, manganese distribution and microstructure composition, effect of alloying mode," in Application of Thermodynamics to Biological and Materials Science, M. Tadashi, Ed., vol. 22, pp. 573-602, InTech, Rijeka, Croatia, 2011.

[20] E. Hryha, E. Dudrova, and L. Nyborg, "On-line control of processing atmospheres for proper sintering of oxidationsensitive PM steels," Journal of Materials Processing Technology, vol. 212, no. 4, pp. 977-987, 2012.

[21] E. Hryha, L. Nyborg, C. Gierl, H. Danninger, and S. Bengtsson, "Surface analysis of prealloyed steel powders: qualitative and quantitative aspects," in Proceedings of the PM2010 World Congress and Exhibition, vol. 1, pp. 25-32, EPMA, Florence, Italy, 2010.

[22] E. Hryha and L. Nyborg, "Changes in oxide chemistry during consolidation of Cr/Mn water atomized steel powder," Powder Metallurgy Progress, vol. 11, no. 1-2, pp. 42-50, 2011.

[23] E. Mosca, "Controlled atmospheres in powder metallurgy, in sintering theory and practice," Intensive Short Course, EPMA, Torino, Italy, 1996.

[24] P. Beiss, "Sintering atmospheres for PM steels," in Proceedings of the Höganäs Chair in Powder Metallurgy Workshop Sintering Atmospheres, Vienna, Austria, 1999.

[25] G. F. Bocchini, "Influence of controlled atmospheres on the proper sintering of carbon steels," Powder Metallurgy Progress, vol. 4, no. 1, pp. 1-34, 2004.

[26] J. Ardvidsson, "On-line measurement of sintering atmospheres," in Proceedings of the World Congress PM98, vol. 2, pp. 253-260, EPMA, Grenada, Spain, 1998.

[27] P. Ortiz and F. Castro, "Thermodynamic and experimental study of role of sintering atmospheres and graphite additions 
on oxide reduction in Astaloy CrM powder compacts," Powder Metallurgy, vol. 47, no. 3, pp. 291-298, 2004.

[28] P. Ortiz and F. Castro, "Study of gas solid interactions during sintering of Cr-containing PM steels," in Proceedings of the PM2003 Conference, vol. 1, pp. 243-248, EPMA, Valencia, Spain, 2003.

[29] L. M. Berger, S. Stolle, W. Gruner, and K. Wetzig, "Investigation of the carbothermal reduction process of chromium oxide by micro- and lab-scale methods," International Journal of Refractory Metals and Hard Materials, vol. 19, no. 2, pp. 109-121, 2001.

[30] W. Gruner, S. Stolle, and K. Wetzig, "Formation of $\mathrm{CO}_{x}$ species during the carbothermal reduction of oxides of $\mathrm{Zr}, \mathrm{Si}, \mathrm{Ti}, \mathrm{Cr}, \mathrm{W}$, and Mo," International Journal of Refractory Metals and Hard Materials, vol. 18, no. 2, pp. 137-145, 2000.

[31] H. Danninger and C. Gierl, "Processes in PM steel compacts during the initial stages of sintering," Materials Chemistry and Physics, vol. 67, no. 1-3, pp. 49-55, 2001.

[32] H. Danninger, C. Gierl, S. Kremel, G. Leitner, and K. Jaenicke-Roessler, "Degassing during sintering of different Fe and $\mathrm{Fe}-0.8 \% \mathrm{C}$ powder compacts," in Proceedings of the PM World Congress Sintering (PM98), vol. 2, pp. 342-346, EPMA, Grenada, Spain, 1998.

[33] H. Danninger, C. Gierl, S. Kremel, G. Leitner, K. JaenickeRoessler, and Y. Yu, "Degassing and deoxidation process during sintering of unalloyed and alloyed PM steels," Powder Metallurgy, vol. 2, no. 3, pp. 125-139, 2002.

[34] H. Danninger, C. Gierl, S. Kremel, G. Leitner, and K. JaenickeRoessler, "A simple method to study the degassing and reduction processes during sintering of ferrous powder compacts," P/M Science \& Technology Briefs, vol. 6, no. 3, pp. 10-14, 2004.

[35] H. Danninger, C. Xu, and B. Lindqvist, "Oxygen removal during sintering of steels prepared from $\mathrm{Cr}-\mathrm{Mo}$ and Mo prealloyed powders," Materials Science Forum, vol. 534-536, no. 1, pp. 577580, 2007.

[36] M. Hrubovcakova, Microchemistry of interfaces in sintered microstructure of sintered high-strength steels [Ph.D. thesis], IMR SAS, Košice, Slovakia, 2011.

[37] M. Hrubovcakova, E. Dudrova, and J. Harvanova, "Influence of carbon content on oxide reduction during sintering of Cr-MoC pre-alloyed steel," Powder Metallurgy Progress, vol. 11, no. 1-2, pp. 115-122, 2011.

[38] M. Dlapka, Sinterhardening grade steels with sufficient toughness for synchronizer hub applications [Ph.D. thesis], TU, Vienna, Austria, 2011.

[39] O. Bergman, Key aspect of sintering powder metallurgy steel prealloyed with chromium and manganese [Ph.D. thesis], Chalmers University of Technology, Gothenburg, Sweden, 2011. 

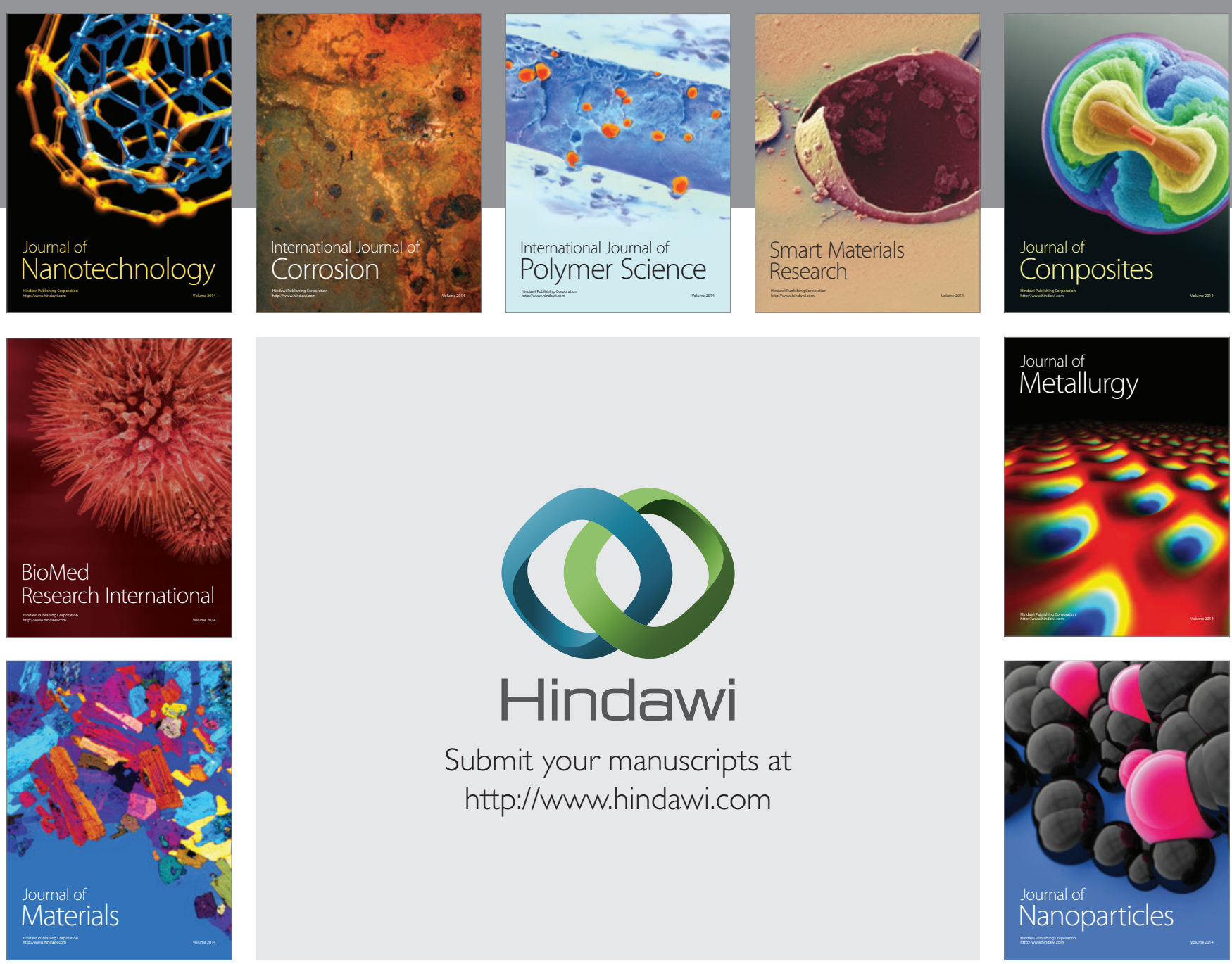

Submit your manuscripts at http://www.hindawi.com
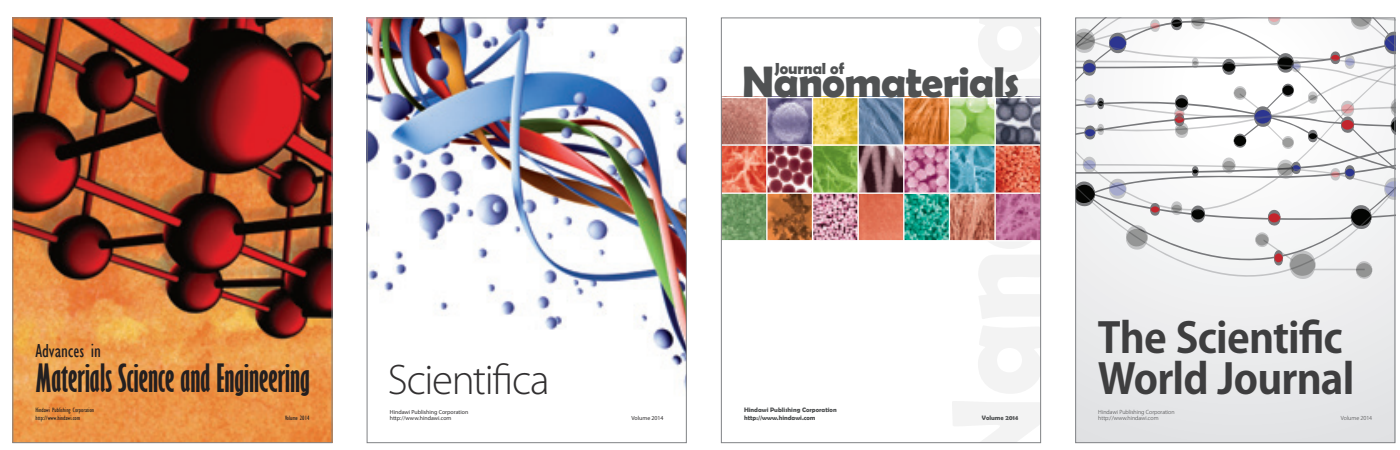

\section{The Scientific World Journal}
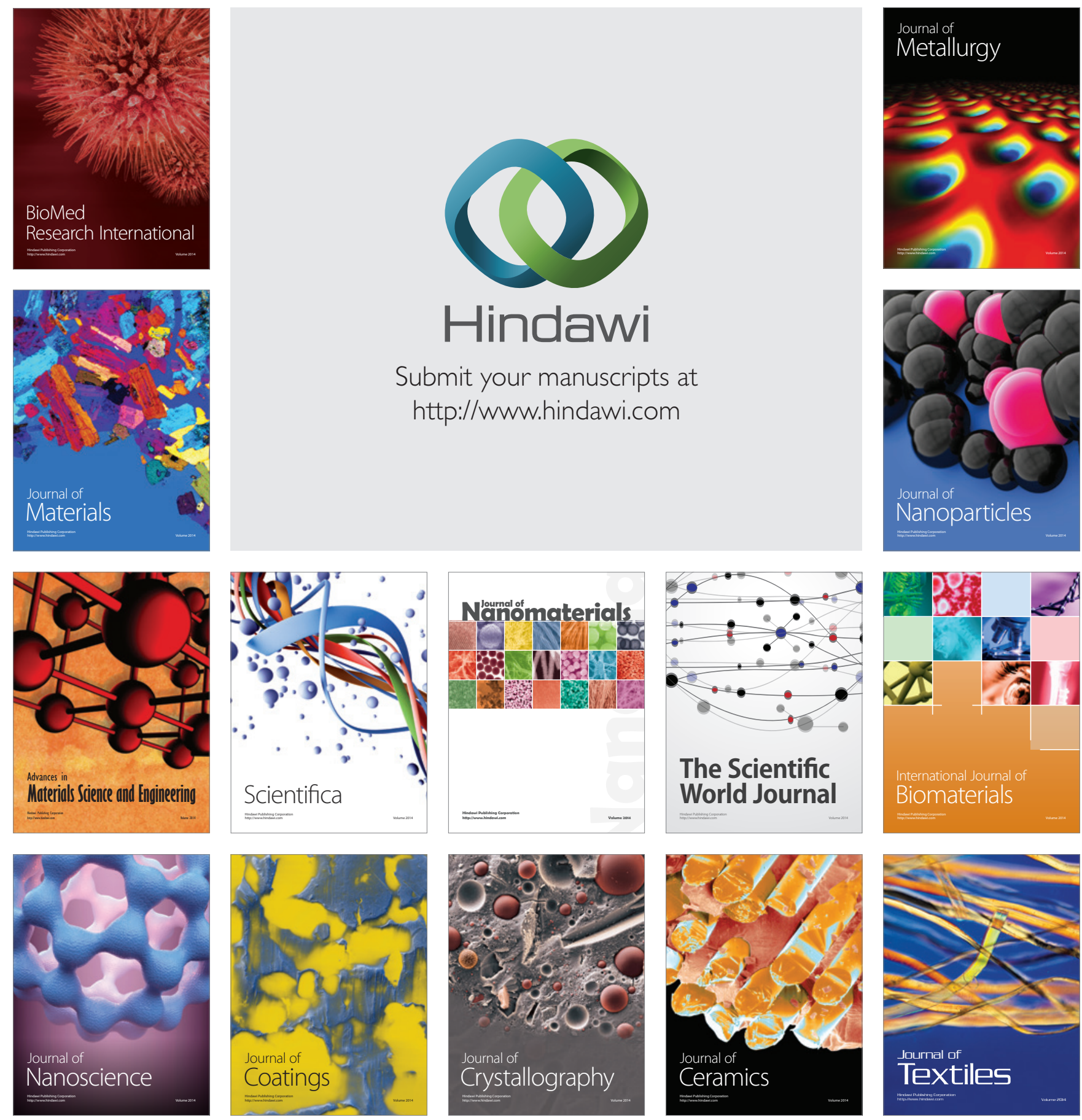